\title{
Oiling the Bureaucracy? Political Spending, Bureaucrats and the Resource Curse*
}

\author{
Adam S. Harris ${ }^{1}$, Rachel Sigman ${ }^{2}$, Jan Meyer-Sahling ${ }^{3}$, Kim Sass \\ Mikkelsen $^{4}$, and Christian Schuster ${ }^{1}$ \\ ${ }^{1}$ University College London \\ ${ }^{2}$ Naval Postgraduate School \\ ${ }^{3}$ University of Nottingham \\ ${ }^{4}$ Roskilde University
}

May 2019

\begin{abstract}
What role do bureaucrats play in the development of the resource curse in countries that have recently discovered oil? Much of the resource curse literature argues that political leaders spend natural resource revenue in ways that entrench their political power but undermine longer-term economic development. This literature has largely overlooked the role of bureaucrats - those responsible for the day-to-day operations of the state. Bureaucrats may support or constrain political spending in ways that minimize the resource curse. Using results of a survey experiment with over 3,000 government employees in Ghana and Uganda, two countries with recent oil and gas discoveries, we find that bureaucrats treated with information on oil revenue are more likely to disapprove of spending practices that benefit political supporters. The results also suggest that material motivations may be at play: bureaucrats in Uganda who are secure in their jobs and outside of government patronage networks are most likely to oppose the political use of oil revenue. These findings challenge unitary state assumptions underlying much of the resource curse literature, especially for new oil producers. They also suggest that policymakers ought to engage civil servants in efforts to avoid or curtail the resource curse.
\end{abstract}

${ }^{*}$ Harris and Sigman are joint lead authors; the remaining three authors are listed in alphabetical order. This project is supported by the UK Department for International Development Anti-Corruption Evidence (ACE) program, Co-PIs: Jan Meyer-Sahling and Christian Schuster. Ethical review provided by the University of Nottingham. This paper addresses one part of the broader experiment investigating the relationship between oil revenue and bureaucrats. Pre-Analysis Plan available at EGAP: http://egap.org/registration/2661. We are grateful to Abdul-Gafaru Abdulai, Leonard Anaman, Daniel Appiah, Immaculate Apio Ayado and the many enumerators in Ghana and Uganda who contributed to the implementation of the survey. We also thank Mai Hassan, Kristen Kao, attendees at the Spring 2018 WGAPE meeting at UCLA and at the Oxford Department of Politics and International Relations for their helpful comments. 
"It must be handled by a civil servant. It is wrong for the political people to be involved in Finance or Administration. Ours is policy, plans and supervision. Finance and administration is for the civil servants."

-Yoweri K. Museveni, President of Uganda, November 4, 2018. ${ }^{1}$

\section{Introduction}

A large literature on the politics of the resource curse establishes that leaders spend resource revenues to entrench their political power (Ross, 2001a; Morrison, 2009). In favoring consumption over production, these spending strategies tend to impede long-run economic performance in resource-rich countries throughout the developing world (Anderson, 1987; Karl, 1997; Chaudhry, 1997; Yates, 1996; Sachs and Warner, 2001; Ross, 2001b; Atkinson and Hamilton, 2003; Lewis, 2009; Dauvin and Guerreiro, 2017). There is considerably less agreement, however, about how political leaders implement these spending strategies and under what circumstances they may be constrained from doing so. Factors such as social mobilization (Auty, 1994; Saylor, 2014), inequality (Dunning, 2008), institutional quality (Robinson et al., 2006; Menaldo, 2016), political settlements (Hickey et al., 2015) and economic structure (Khanna, 2017) have all been used to explain when and how political leaders use resource revenue for their political advantage. ${ }^{2}$

Although they invoke different explanations, these theories share the common assumption that bureaucratic officials simply implement the revenue management strategies dictated by political leaders. Yet, as Hertog argues, resource-producing states possess "highly varied [institutional] components" (2010, 3) where "small-scale social networks in the bureaucracy" $(2010,4)$ can affect policy outcomes. This suggests that political leaders could face principal-agent problems in implementing their preferred spending strategies.

This article applies principal-agent theory to understand the potential roles of bureaucrats

\footnotetext{
${ }^{1}$ President Museveni's website (accessed December 10, 2018): https://www.yowerikmuseveni.com/ clarification-confusion-surrounding-youth-programmes.

${ }^{2}$ For an earlier overview of these approaches, see Ross (1999).
} 
in processes of rentierization. ${ }^{3}$ We investigate whether bureaucrats support or oppose the political spending strategies of political leaders in contexts of new or increasing oil revenue. Such principal-agent problems may constrain politicians' abilities to use resource revenue for their political advantage and, ultimately, shape their decisions about how to employ, sidestep or reform state institutions in the face of resource revenue windfalls.

We examine bureaucratic responses to oil revenue using results from a survey experiment with over 3,000 government employees in Ghana and Uganda, two countries where recent discoveries of oil are projected to deliver significant sums of money to government coffers in coming years. ${ }^{4}$ The experimental design, in which respondents are randomly assigned to receive information about the state's future oil revenue, enables us to estimate the effect of increased oil revenue on bureaucrats' attitudes towards politically-motivated spending. Choosing cases with recent oil discoveries is particularly useful for theorizing the processes through which the introduction or expansion of oil revenue leads to spending patterns commonly associated with rentier states, and the specific roles that bureaucrats may play in those processes. This focus on 'rentierization' is important given increasing numbers of recent oil and gas discoveries in Africa and throughout the world.

Our findings run contrary to widespread assumptions throughout the resource curse literature. Bureaucrats may indeed oppose politicians' efforts to spend resource revenues in politically advantageous ways. This response is most apparent among Ugandan bureaucrats who feel secure in their jobs but who remain outside of government patronage networks. These findings suggest, among other things, the importance of material motivations for understanding bureaucrats' responses to changes in government revenue. Additionally, we find that opposition to political spending may result from both generic and oil-specific increases in government revenues, but the magnitude of the effect is higher for oil revenue.

\footnotetext{
${ }^{3}$ See Moe (1989) and Gailmard and Patty (2007) for general articulations of principal-agent theory as it relates to political control of the bureaucracy. For studies of divergent interests between politicians and bureaucrats in Africa, see Hassan and O'Mealia (2018); Poteete (2003) and, with respect to donors, see Johnson (2015).

${ }^{4}$ Production in Ghana is active but has not yet begun in Uganda.
} 
The results in Ghana are somewhat different: we find no statistically significant effects of the oil revenue prime treatment. The differing results across the two countries permit us to speculatively theorize three possible variables - political competition, stage of oil production, and economic structure - that explain the contexts in which bureaucrats would be more or less likely to act as a constraining force on politicians seeking to spend revenues in ways that detract from longer-term development. Our discussion of these contextual variables outlines fruitful avenues for future research regarding the role of bureaucrats in facilitating or impeding the resource curse.

While the survey experiment speaks only to attitudes of bureaucrats and our inferences are based on survey responses, which may be prone to biases, we do provide suggestive evidence that these attitudes are correlated with relevant behavior and that civil servants in these contexts have the space to resist ruling party directives with which they disagree. Moreover, we show that attitudes are important in their own right: if bureaucrats oppose the spending directives given by political principals, they are likely to become less committed to their work, less motivated to do their jobs, and more likely to shirk their responsibilities, all of which have broader implications for politicians' abilities to use oil revenue for political gain.

Our findings have both theoretical and practical implications. First, they underscore the need to question the unitary state assumption that underpins much of the political economy of the resource curse literature. Instead, the spending patterns associated with resource revenue windfalls are likely to unfold in states characterized by a multitude of actors, including bureaucrats, and not all of these actors will automatically fall in line with incumbents' strategies of resource revenue spending. Moreover, how political leaders respond to the types of principal-agent dynamics explored in this study may affect the longer term politicization, capacity and effectiveness of bureaucracies in resource-producing states. On a practical level, the findings are relevant for the many organizations and actors seeking to strengthen institutions and transparency surrounding resource extraction. Bureaucrats may constitute a 
potential avenue through which to constrain politicians prone to the mismanagement of resource revenues, particularly if their jobs are secure and they are not embedded in the ruling party's patronage network.

In the next section we discuss potential roles of bureaucrats in the resource curse, and develop a set of theoretical expectations regarding how bureaucrats may respond to increases in natural resource revenue. Section 3 presents information about the political, bureaucratic and resource contexts of Ghana and Uganda. In Section 4 we describe the survey and sampling procedures as well as the specific design of the priming experiment followed, in Section 5 , by the results. We conclude with a discussion of the findings and their implications.

\section{Political Spending and the Resource Curse}

New discoveries of major oil and gas deposits in and around sub-Saharan Africa promise to deliver significant sums of additional revenue to at least 10 countries in the coming years. ${ }^{5}$ Such discoveries have raised concerns about the proliferation of the resource curse across the continent, particularly as politically stable countries such as Ghana, Senegal, Tanzania, and Uganda introduce oil and gas production into their economies. The experiences of these countries will provide important new evidence about when and how resource extraction undermines democratic institutions, entrenches authoritarianism, or worsens corruption in ways that impede longer-term production and economic growth. ${ }^{6}$

At the heart of concerns about the expansion of oil extraction across Africa (or elsewhere) is what Ross (2001a) calls a "spending effect" of oil revenue. ${ }^{7}$ The introduction of resource revenue increases the value of holding power, thereby incentivizing politicians

\footnotetext{
${ }^{5}$ Including Ghana, Uganda, Ethiopia, Kenya, Mozambique, Senegal, Mauritania, Sierra Leone, Tanzania and Sao Tome and Principe. New deposits have also been found in existing oil producers such as Angola and Nigeria.

${ }^{6}$ There is a voluminous literature on the effects of natural resource revenue on political and governing institutions. For overviews, see Ross (2015); Frankel (2010); Rosser (2006).

${ }^{7}$ Another strand of the literature emphasizes the weakening of accountability structures as tax revenue is displaced by resource rents. Though we did explore this resource curse mechanism in our experiment, it will be covered in a separate paper.
} 
to allocate more resources to staying in power (Caselli and Cunningham, 2009; Morrison, 2009). ${ }^{8}$ These spending practices may deplete foreign exchange, increase debt burdens and crowd-out investments in more productive sectors (Anderson, 1987; Karl, 1997). They are most commonly associated with rentier states - those that derive a large proportion of their revenues (usually at least 50\%) from external rents (Mahdavy, 1970; Ross, 2001a) - but spending effects also occur in states where natural resource rents comprise an important, but not major, source of revenue, particularly throughout the developing world (Dauvin and Guerreiro, 2017). ${ }^{9}$

Where spending effects are present, political leaders seek to use resource revenue to entrench their power in a number of ways. They do so by monopolizing access to resource revenue and rewarding political supporters by providing jobs in the state apparatus (Robinson et al., 2006, 450) or goods and services around election time (Odedokun, 1990). These types of spending help to shore up support for the incumbent and placate potential opposition movements (Morrison, 2014). Incumbents may also seek to solidify their political advantage by investing in tools of repression (Wright et al., 2015; Cotet and Tsui, 2013; Ross, 2001a; Collier and Hoeffler, 1998) or allowing for parallel administrative structures (Hertog, 2010). In the former, governments invest in their security forces and repress opposition, rather than (or in addition to) providing goods and services to shore up support. In the latter, they may set up parallel administrative structures where politicians or close associates can exert greater control over the use of oil revenue. This has been the case, for example, in Angola where the political leadership often uses the state-owned oil company Sonangol and its subsidiaries, for a wide range of bureaucratic functions including allocation, investment and distribution of state oil revenues. ${ }^{10}$ Where governments pursue either of these strategies, the bureaucracy may stay intact but becomes less powerful in their ability to influence

\footnotetext{
${ }^{8}$ For in-depth statistics on spending patterns in resource-extracting states, see Ross (2012).

${ }^{9}$ For example, see Caselli and Michaels (2013) on spending effects in Brazil. Moreover, increasing scrutiny of the endogeneity of resource dependence to wealth (Badeeb et al., 2017; Kropf, 2010) suggests that the distinction between rentier states and others with significant resource extraction may be overstated.

${ }^{10}$ See, for example, Croese (2017) on Sonangol's role in the provision of public housing.
} 
spending decisions.

Our focus is on cases where incumbents use the existing bureaucracy to deliver the benefits of resource windfalls. The unitary state assumption in most such cases is that bureaucrats comply with politician directives about how to spend oil revenue. For example, upon the introduction of oil revenue in Venezuela, Karl (1997) observes that the bureaucracy had been, even prior to oil production, structured to "promote centralization, rent seeking, and obedience to presidential authority" $(1997,138)$. This structure enabled the Perez administration to monopolize new oil revenue and use it to entrench the party's political advantage, leading to further centralization of bureaucratic authority $(1997,90) .{ }^{11}$

In some cases, however, bureaucrats may have their own goals and interests. For example, Chaudhry (1997) describes how the introduction of oil revenue in Saudi Arabia precipitated the bureaucracy's move away from direct taxation of individuals. This shift in revenue eroded the informational basis on which bureaucrats made programmatic decisions leading "the largely Nejdi bureaucracy to create allocative decisions to favor the kin and region of bureaucrats" (1997, 190). In another account of the Saudi bureaucracy, Hertog goes even further to describe "bureaucratic sluggishness" and "self-interest on a micro-scale" that can aggregate to act as "a diffuse veto over policies" $(2010,19)$. In other words, the introduction of oil revenue is not necessarily accompanied by political control over bureaucrats. ${ }^{12}$

As these accounts make clear, bureaucratic responses to the introduction of oil production may vary and are deserving of greater attention. Bureaucrats not only occupy positions where they can assist politicians in the realization of their political goals, but, as a large bureaucracy literature underscores and as we elaborate in the next section, their interests often diverge from those of politicians in a number of ways.

\footnotetext{
${ }^{11}$ See also Michael Ross' (2001b) account of institutional changes in the forestry sector in Indonesia.

${ }^{12} \mathrm{~A}$ possible alternative is that incumbents use resource revenue to shape the bureaucracy to their will, for example by granting jobs to loyalists (Ross, 2001b; Robinson et al., 2006). This process occurs, arguably, in the longer-term and is a likely consequence of the dynamics explored in this paper.
} 


\section{Principal-Agent Problems Amidst Increasing Resource Revenue}

Past research has largely assumed away any principal-agent problems facing political leaders with access to oil revenues, focusing instead mainly on the power and proclivities of politicians to use resource revenue in their quests to maintain power. Because resource revenue enables incumbent political leaders to spend in ways that help them to entrench their power, bureaucrats' reactions to these spending practices may depend on whether their interests are served by an increase in incumbent power.

Our principal-agent model is deliberately simple as it is the first articulation of the principal-agent problem regarding bureaucrats in the process of renteirization. The principals are conceived as political leaders: presidents, ministers or other high-ranking political appointees. ${ }^{13}$ Agents in this case are bureaucrats who occupy any public service post that is not formally a political appointment. Bureaucrats in this case may be hired with the help of politicians, but they do not occupy posts that are formally defined as political appointments, and their tenure is, at least formally, typically longer than that of a presidential term. In the conclusion, we highlight possible extensions to the model that bring in more complexity by disaggregating types of principals and agents.

We theorize five possible principal-agent dynamics that are likely to affect the ability of politicians to spend resource revenues in ways that help them to entrench their political power. While these hypotheses are not the only ways in which principal-agent problems may affect the success or failure of politicians' spending strategies, they represent important dynamics that are likely to occur in the context of new oil producing states throughout the developing world.

Our first hypothesis makes explicit the widespread assumption throughout the resource

\footnotetext{
${ }^{13}$ We use the terms "politicians" and "political leaders" interchangeably. Assuming principals are only politicians indicates that in our model higher-level bureaucrats do not give directives to spend revenue for political purposes or, in line with past studies (McCubbins et al., 1987), that lower-level bureaucrats see such directives from higher-ranking bureaucrats as originating from politicians. While this does abstract from reality, in order to maintain parsimony in this first investigation, we seek to simplify the profile of principals and agents and leave desegregation of these groups to future studies.
} 
curse literature that bureaucrats act simply as agents of political leaders. In its most basic form, the resource curse theory suggests that bureaucrats comply with politicians who are seeking to use resource revenue to entrench their power. Further, this perspective sees that politicians and bureaucrats are free to do so because, in the absence of taxation, citizens are less likely to hold politicians accountable for such actions (de la Cuesta et al., 2017; Prichard et al., 2018). If bureaucrats act simply as agents of politicians, we should expect them to be more supportive of politically-motivated spending in the face of oil revenue windfalls, much like Karl (1997) describes in the case of Venezuela. In this case, bureaucrats act simply as 'instruments' of the government (Finer, 1941).

Hypothesis 1. When bureaucrats learn of increases in oil revenue, they become more accepting of the use of state resources for political gain. ${ }^{14}$

However logical this "unitary-state" approach may seem in the revenue context, it likely overstates the extent to which bureaucrats' interests align with those of politicians who are seeking to expand their power. Interests of politicians and bureaucrats may diverge for any number of reasons (Moe, 1989; Gailmard and Patty, 2007). For instance, in contexts of weak rule of law and rule compliance, bureaucrats have fewer incentives to comply with legislation or executive authority (Huber and McCarty, 2004) - a condition common in African states where political leaders have often struggled to establish formal authority and control over the state (Huntington, 1968; Herbst, 1999). For example, despite political desires to privatize in the 1990s, bureaucrats in democratic Botswana successfully prevented further privatization of range land (Poteete, 2003). Further, in Tanzania, during the push for one-party socialism under President Nyerere, many regional and district-level bureaucrats pushed back against party officials who were directing development efforts at the region and district levels. Administrators resisted party influence by isolating party officials from the main activities of governance because they believed that the party was overstepping its role

\footnotetext{
${ }^{14}$ The precise wording from the pre-analysis plan is: "Respondents receiving the treatment prime should demonstrate greater levels of acceptance for the diversion of state resources for political gain."
} 
with undo political influence on the bureaucracy (Picard, 1980).

While the introduction of oil revenue may increase politicians' interests in maintaining power (because the value of power increases and accountability constraints may weaken), bureaucrats' interests may diverge from politicians' spending interests. We theorize four possible ways in which the interests of bureaucrats diverge from politicians to shape their responses to increases in oil revenue.

First, bureaucrats want to retain their jobs. An interest in job security is a fundamental concern of bureaucrats across diverse contexts including, for example, the U.S. (Perry et al., 2010), Taiwan (Chen and Hsieh, 2015) and Ghana (Price, 1975). Moreover, job security is linked to a wide range of bureaucratic behaviors including employees' levels of effort at work (Frank and Lewis, 2004), their levels of public service motivation (Chen and Hsieh, 2015), and a reduced likelihood to engage in electoral activities (Oliveros and Schuster, 2018).

Job security is particularly important to bureaucrats in developing countries where public service jobs offer security in ways that most private- or informal-sector jobs do not. In an early study of bureaucrats in Ghana, Price notes that "many [survey] respondents felt it unwise to move to a private business firm, no matter how large and well established and no matter how high the salary, because in their view such an establishment might at anytime collapse, with a consequent loss of employment, while the civil service would continue forever" $(1975,181)$. In our survey, $67.4 \%$ of respondents in Uganda and $62.7 \%$ in Ghana said that, if forced to look for a new job, they would prefer to find a job in the public sector rather than the private sector. Bureaucrats may therefore be expected to have a strong interest in retaining their jobs.

Since resource revenue increases the value to politicians of staying in office (and provides a means to maintain office), they will be more likely to retain bureaucrats that support their spending strategies and dismiss or transfer those who oppose them. To ensure retention of their jobs in the midst of this change, bureaucrats who do not feel protected from dismissals may thus be expected to be more accepting of political directives to use oil revenue for 
political purposes. By contrast, the interests of those who feel more secure in their jobs need not be aligned with political principals: they can oppose politicians' efforts to use oil revenue for political advantage without fearing for their jobs. ${ }^{15}$

Hypothesis 2. When bureaucrats with greater job security learn of increases in oil revenue, they are more likely to oppose the use of state resources for political gain.

Next, differential political motivations may shape whether bureaucrats oppose spending of oil revenues for political advantage. They may enter the public service as loyal agents of a party or politician (Grindle, 2012; Piattoni, 2001), or they may engage in acts of political loyalty to advance one's career (Lentz, 2014). These political motivations are likely to shape how they respond to politicians' efforts to direct oil revenue spending towards political supporters.

If all bureaucrats were hired based on their political affiliations or loyalty, we would expect all bureaucrats to act as political agents in the management of resource revenue. However, bureaucratic institutions vary widely in the extent to which employees are recruited politically (Dahlström et al., 2015; Johnson, 2015; Gingerich, 2013), motivated politically (Peters, 2002), as well as the types of corruption bureaucrats undertake in service to their political patron (Gingerich, 2013; Oliveros and Schuster, 2018). Such variation is likely to produce bureaucratic personnel with diverse political motivations, some of whom will oppose the ruling party's use of oil revenues for political advantage.

Hypothesis 3. When bureaucrats who do not support the ruling party learn of increases in oil revenue, they are more likely to oppose the use of state resources for political gain.

A large literature discusses the ways that bureaucrats seek to derive economic benefits from their positions (Rose-Ackerman, 1999; Krueger, 1974). Bureaucrats may engage in rentseeking for a wide variety of reasons: to supplement incomes, to respond to social pressures

\footnotetext{
${ }^{15}$ Brierley (2016), for example, provides evidence that local bureaucrats in Ghana who fear transfers will partake in party-directed corruption. Similarly, Oliveros (2016) shows that Argentinian bureaucrats support incumbents by providing favors to voters when their jobs are in jeopardy.
} 
(De Sardan, 1999; Foltz and Opoku-Agyemang, Foltz and Opoku-Agyemang) or, in some cases, to retain their jobs. As Shleifer and Vishny (1993) explain, "if jobs are distributed among officials through an auction mechanism, whereby those who pay the most for a job get it, then the prospective officials who do not collect bribes simply cannot afford jobs" (1993, 603). These perspectives suggest that bureaucrats have strong incentives to collect rents beyond their salaries.

How would the introduction of oil revenue affect bureaucrats interested in obtaining rents? If the bureaucrat is embedded into the ruling party's patronage networks, she may derive material benefit from incumbents' efforts to direct spending to political supporters. The bureaucrat may benefit either directly through side payments, promotion, or a more prominent position in the network due to willingness to follow ruling party directives, or indirectly through the benefits siphoned to supporters like herself. If the bureaucrat is not enmeshed in the ruling party's patronage networks, however, she would be less likely to benefit materially from politicians' efforts to direct resource revenue to political supporters.

This means that bureaucrats outside of existing patronage networks may be less inclined to support ruling party efforts to use resource revenues for political ends, since they or their communities are less likely to derive benefits from such spending. Moreover, if incumbent political leaders use resource revenue to entrench their power, those outside of ruling party patronage networks will be less able to gain access to material benefits above and beyond one's salary. Thus, those who do not have personal or political connections that yield material or career benefits may be less interested in facilitating government-directed patronage spending that results from resource windfalls. While patronage networks may overlap to some extent with partisan affiliations referenced in Hypothesis 3, they are likely to comprise broader sets of individuals with connections to co-opted politicians or personal connections to higher-ranking officials.

Hypothesis 4. When bureaucrats who are outside of the government patronage network learn of increases in oil revenue, they are more likely to oppose the use of state resources for 
political gain.

Finally, bureaucrats may be driven by a professional motivation to serve the public. ${ }^{16}$ Those with high levels of public service motivation may display a commitment to national or community development, to the missions of their organizations, to the maintenance of professional norms or to the prestige of the public service, all of which can compel attitudes and behaviors that would make them less willing to engage in political directives that benefit only a selected segment of the population.

There are mixed views on the extent to which public service motivations are prevalent in African contexts. Survey research (ours included) has found substantial levels of public service motivation (Sigman, 2015), as do several ethnographic accounts (Leonard, 1991; Lentz, 2014). Others studying African bureaucracies emphasize values and conditions that militate against public service motivation. Accounts of low morale, lacking professional commitment and a "moral economy of corruption" (De Sardan, 1999) suggest that public service motivation may be overshadowed by other, more pressing, material concerns (Price, 1975).

Public service motivation in this context consists of an array of principles and values, such as commitment to national or community service or beliefs that all people should be treated equally, that make an individual more committed to serving one's community, one's organization or working on behalf of all individuals in society. Due to their public-oriented values, we would expect those with stronger public-service motivations to more strongly oppose political leaders' efforts to direct additional natural resource revenue only to their supporters. This leads us to a fifth, and final, hypothesis:

Hypothesis 5. When bureaucrats with high levels of public service motivation learn of increases in oil revenue, they are more likely to oppose the use of state resources for political gain.

\footnotetext{
${ }^{16}$ For overviews of public service motivation, see Crewson (1997); Houston (2000).
} 
Together, these five hypotheses provide an initial framework for understanding variation in the roles of bureaucrats in facilitating or impeding political practices commonly associated with the resource curse. ${ }^{17}$ This incorporation of principal-agent problems into rentier state theory is especially important for understanding processes of 'rentierization' in new oilproducing states, as both politicians and bureaucrats face new choices about spending and management of resource windfalls in the developing world.

\section{Resources, Politics and Bureaucracy in Ghana and Uganda}

Our study focuses on bureaucrats in two African countries: Ghana and Uganda. These cases were selected for this study because 1) they are largely representative of African countries with new oil discoveries, 2) bureaucrats in these countries are involved in the management of oil revenue (Ghana) and pre-oil production decision-making (Uganda); and 3) their key differences - democracy, economic structure and phase of oil production - provide diverse contexts in which to think through the rentierization process and scope conditions of our hypotheses.

Ghana and Uganda are together largely representative of many of the African countries with new discoveries of oil and gas, thereby maximizing external validity. They are reflective of other African countries with new oil and gas discoveries in terms of their economic and political attributes. For example, among countries with newer discoveries of oil and gas, Tanzania and Mozambique are similar to Uganda in terms their levels of economic wealth and dominant-party regimes; while Kenya's higher level of wealth and more competitive political landscape is more similar to the Ghanaian context. Moreover, as others who have drawn

\footnotetext{
${ }^{17}$ Our theory focuses on variation among bureaucrats depending on their presumed interests. However, because bureaucrats are a diverse group, it is possible that other characteristics of bureaucrats, such as seniority, may influence willingness to follow ruling party directives. We briefly investigate heterogeneity in treatment effects across a number of demographic sub-groups in Appendix J.
} 
comparisons between Ghana and Uganda have noted, they reflect many typical developing countries in terms of demographics, life expectancy, and poverty and thus provide good test cases for the effects of oil revenue in developing countries (de la Cuesta et al., 2017; World Bank, 2016; Hickey et al., 2015).

Ghana and Uganda also represent cases in which the governments are managing oil through the existing bureaucracy rather than creating parallel structures that manage state oil revenues. In Ghana, the Petroleum Management and Revenue Act (2011, updated in 2015), calls for an Annual Budget Funding Amount (ABFA) that is allocated to the government budget with Parliamentary approval. Up to this point, the ABFA has funded road, education, health, agriculture and communications projects. ${ }^{18}$ These spending priorities are included in agency budgets published as part of the Ministry of Finance's annual budget statements. In Uganda, the Oil and Gas Revenue Management Policy of 2012 outlines a similar system in which an "Annual Budget Funding Amount" will be transferred to the consolidated fund in the government budget (Government of Uganda, 2012, p. 30-31).

The two countries do, however, vary in ways that may affect the attitudes of bureaucrats as they relate to oil revenue and to the hypotheses described in the previous section. While results based on only two cases cannot speak to the effect of oil in all developing countries with varying political, economic, and social characteristics, the different contexts do provide initial evidence for further theory-building and empirical work regarding these various contextual factors.

First, the two countries differ considerably in their political contexts. Ghana is commonly regarded as one of Africa's most stable democracies. It has seen three alternations of power. In contrast, Uganda is a dominant party regime with authoritarian tendencies under Yoweri Museveni and the National Resistance Movement (NRM). This difference is reflected in the much lower V-Dem Polyarchy score Uganda receives compared to Ghana (see Table 11). Their polities also differ in terms of their political settlements: Uganda with a dominant party

\footnotetext{
${ }^{18}$ Ghana's Public Interest and Accountability Committee tracks oil revenue spending. See http://www . piacghana.org/portal/29/36/the-abfa.
} 
while Ghana is typically seen as having 'competitive clientelism'. As Hickey et al. (2015) have argued, this variation in political settlement can shape the ways that their governments approach and manage oil revenue, particularly in terms of the government's sensitivity to popular demands in the use of oil revenue. Further, Ghana consistently outranks Uganda on indicators of the protection of rights and freedoms (see Table 11 in Appendix B) suggesting that Ghanaians likely have more space to oppose ruling party decisions.

Importantly, Uganda's dominant regime likely has greater opportunities to place loyal supporters in state positions or to co-opt agents to act on their behalf, forcing it to bend to the ruling party's will. This is the case not only because of fewer constraints on the executive in Uganda, but also because the ruling NRM has held power since 1986, giving them over 30 years to build up their corps of loyalists in the bureaucracy. ${ }^{19}$ On the other hand, the real threat of political turnover in Ghana may constrain politicians in their efforts to stack the bureaucracy with political supporters and exert political control. ${ }^{20}$

The second difference is economic. Ghana's GDP per capita is roughly double that of Uganda (World Bank, 2016). ${ }^{21}$ Ghana's economy has historically been supported by exports of gold and cocoa, while Uganda's economy is largely agricultural with coffee as the main export. $^{22}$ Oil revenue accounts for a large sum of Uganda's GDP: $3 \%$ of GDP projected for Uganda once oil production begins compared to 1.6\% of GDP in Ghana in 2016. These economic differences suggest that the relative impact of oil revenue may be smaller in Ghana than in Uganda. Further, Ghana's history of high-value mineral and agricultural exports (gold and cocoa in particular) could mean that the introduction of oil revenue does not constitute as significant of a break with the status quo as in Uganda.

Third, the two countries are in different stages of oil production. Oil was discovered in

\footnotetext{
${ }^{19}$ Evidence from our survey supports these expectations. In particular, analysis of list experiment data (see Appendix C) suggests that bureaucrats in Uganda are more than twice as likely than those in Ghana to have 1) been hired with the help of a politician; and 2) helped divert state resources to the ruling party.

${ }^{20}$ Note that in Section 4.2 we discuss how and to what extent bureaucrats in these contexts are likely to have space to resist ruling party directives.

${ }^{21}$ The difference was somewhat smaller prior to the start of oil production in Ghana.

${ }^{22}$ Uganda also has a number of small mineral deposits including copper and gold.
} 
Ghana in 2007 and production began in 2010. Oil was first discovered in Uganda in 2006 and production is expected to begin in 2020. This difference means that bureaucrats in Ghana may have already experienced the actual effects of oil revenue, while those in Uganda have not yet had this experience. Whether actual experience would heighten sensitivity to the oil prime is an empirical question, and we find below that the effect is stronger in Uganda than in Ghana.

These differences provide some reason to believe that bureaucrats' responses to oil revenue may differ in Ghana and Uganda. While we are unable to determine which of these differences, if any, may affect the findings of our study, understanding key differences between the two countries does provide a means to push this research agenda forward.

\section{Empirical Strategy}

We test our hypotheses using data from a survey experiment that primes central government employees with information about future oil revenue, then asks respondents about their attitudes toward the political use of oil rents. A priming experiment is an effective way to explore bureaucrats' responses to changes in revenue for several reasons. First, it facilitates a potential causal interpretation of the results with regards to the salience of oil revenue in bureaucrats' attitudes toward ruling party spending strategies. Second, scholars have sought to establish the exogeneity of oil at the national level with some success (Ross, 2015), but our method provides a means to establish exogeneity at the individual level. Finally a survey allows us to gather key data for bureaucrats in Africa, a population for which studies have so far provided limited systematic data. This section describes the design of this priming experiment and provides information about the implementation of the broader survey in which the experiment was embedded. 


\subsection{Experimental Design}

Building on the approach of de la Cuesta et al. (2017) in their survey experiment with citizens, we employ a between-subjects design in which respondents within each country are randomly assigned to one of three groups: a treatment group that sees information regarding projected oil revenue, a placebo group receiving a message about generic revenue increases, or no prime at all (control). By priming on the projection of future revenues, we are able to develop similar messages for the two countries despite different stages of oil production. We do note that the use of projected revenues may make it difficult to detect how bureaucrats in Uganda would respond when revenue windfalls are actualized (we discuss this further in Section 5.6).

The treatment and placebo messages in the two countries are presented in Figure 1 (the placebo is identical in the two countries). The logic of the placebo is that any observed effects from the treatment could be due to generic increases in government revenue, rather than increases that are specific to oil. To test whether the placebo is acting as a treatment, we also pose a follow-up question that asks placebo respondents which forms of revenue came to mind when the information was presented to them. The control group, which receives no prime at all, is designed to provide a baseline against which those receiving the treatment and the placebo are compared. ${ }^{23}$

The $\$ 500$ million amount of increase in oil revenue in the treatment in each country was chosen because it was high enough to be reasonable in Uganda and low enough to be reasonable in Ghana. The Ugandan government is expected to earn $\$ 3.6$ billion dollars in revenue per year once oil production begins (Oketch, 2014). ${ }^{24}$ In Ghana, the government estimates that revenue will range from $\$ 252$ Million to $\$ 787$ Million per year (Government of Ghana, 2015). Using the $\$ 500$ million figure then allows us to avoid the use of deception

\footnotetext{
${ }^{23}$ The number of respondents assigned to each group are as follows. Ghana: control $=512$, treatment $=$ 539 , placebo $=557$. Uganda: control $=503$, treatment $=516$, placebo $=485$.

${ }^{24}$ This is based on oil prices in 2013-2014, which have since declined and risen again.
} 
Figure 1: Treatment Conditions

Ghana Treatment: Did you know that over the next few years, government ministries, departments and agencies will receive at least $\$ 500$ million in additional revenue from oil production compared to the last few years? However the amount of revenue collected through taxes from citizens is unlikely to change.

Uganda Treatment: Did you know that over the next few years, government ministries, departments and agencies will receive at least $\$ 500$ million in additional revenue from oil once production begins? However, the amount of revenue collected through taxes from citizens is unlikely to change.

Placebo (both countries): Did you know that over the next few years the revenue of government ministries, departments and agencies will increase by at least an additional $\$ 500$ million?

in the experiment while also making the treatments comparable across contexts. ${ }^{25}$

After the prime, all respondents are asked to indicate their level of agreement with the following statement on a 5-point scale: "Governments should have the right to increase public spending for districts that help them get elected." ${ }^{26}$ If Hypothesis 1 is correct, then respondents who receive the oil revenue treatment should be more likely to agree with the statement, indicating that bureaucrats are more willing to follow political directives in the presence of increasing oil revenue. However, if the assumptions of the resource curse literature are not correct and bureaucrats interests are not aligned with those of politicians (as articulated in Hypotheses 2-5), then the oil revenue treatment would lead respondents to be more likely to disagree with the statement. In Figure 2 we show that overall responses to the post-treatment question are similarly distributed across the two countries. A large majority of respondents strongly disagreed with the statement (65-80\%), while only about $10 \%$ or less

\footnotetext{
${ }^{25}$ This does however provide some limitations: 1) the figure is an underestimate of eventual production in Uganda and 2) using the exact same figure in each county is not the same because the purchasing power of this amount is likely to be greater in Uganda than in Ghana. However, in the context of the survey experiment we sought to make the treatments as comparable as possible for respondents receiving this information across contexts and thus determined that the same number would be the most comparable.

${ }^{26}$ This outcome is appropriate because, in both countries, 1) public funds are often used for political purposes and 2) oil production is (or will be) jointly managed by multinational companies and the government. Additionally, the term "government" is, in both countries, widely accepted to mean the political leadership consisting of the President, Vice President and cabinet ministers. In both countries, ministers are primarily drawn from the ruling party.
} 
Figure 2: Response Distribution in Post Experiment Question

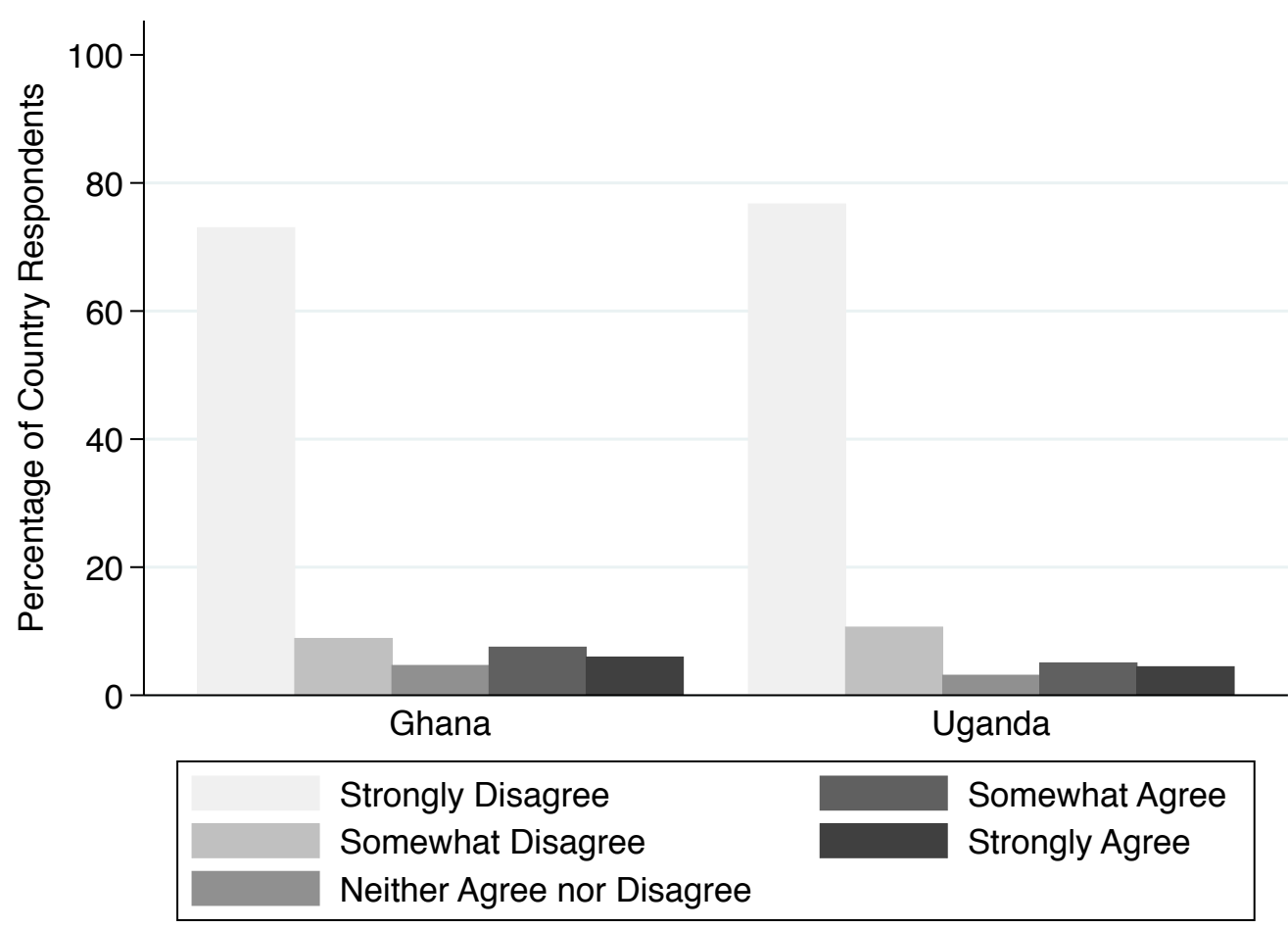

in each country respond that they either somewhat agree or strongly agree with the statement. In both countries, those assigned to the control group had the highest cross-country correlation in their response to the post-experiment question. ${ }^{27}$

We consider a positive response (agreement with) the outcome question under treatment to indicate that the prime has an effect of increasing bureaucrats' support for ruling party spending strategies, while negative responses (disagreement) would indicate that the prime induces bureaucrats' interests to become more divergent from the ruling party.

Of course, this outcome measure is only attitudinal rather than behavioral. It may suggest, but does not necessarily imply, that an individual would act to prevent politicians from using resource revenue to their political advantage. An attitudinal response is appropriate in this context because Uganda in particular does not yet have oil revenue to use for political

\footnotetext{
${ }^{27}$ The skewed distribution of responses seen in Figure 2 introduces the possibility of floor effects, meaning that treated respondents could not more strongly disagree than their baseline (untreated) response. This means that it is possible that any negative effects of the prime would be stronger had we asked a question with greater gradation in levels of disagreement.
} 
purposes. Moreover, our survey evidence suggests, in line with findings from Paler (2013) and de la Cuesta et al. (2017), that attitudinal and behavioral measures are often highly correlated. Paler (2013) and de la Cuesta et al. (2017) measure both attitudinal and behavioral outcomes among citizens in Ghana, Uganda, and Indonesia regarding their willingness to hold elected leaders accountable under tax, aid, or oil-funded governments. The results and conclusions for both types of measures in both studies are identical. In Appendix L, we provide evidence to suggest that attitudinal measures in our survey are also highly correlated with relevant behavioral measures that we tested at the end of the Uganda survey. ${ }^{28}$ This does not conclusively show that bureaucrats in Ugandas authoritarian setting will, in fact, resist ruling party directives once oil revenues accrue, but does provide at least suggestive evidence to this end.

Not only are attitudinal measures correlated with behavioral measures, but our survey also suggests that bureaucrats in Ghana and Uganda are in a position to act against the ruling party. First, across both countries, slightly less than half (only 48\%) of respondents felt that they could be easily dismissed from their jobs and only a third said they are worried about being dismissed for political reasons. ${ }^{29}$ Further, we also asked respondents how often "I feel worried that someone from the ruling party will not approve of my work", and only $6 \%$ of respondents, evenly distributed across both countries, said that they worry about this often or almost always (85\% said rarely or never and $9 \%$ said sometimes). These responses suggest that the bureaucrats surveyed are not overly concerned about ruling party reactions to their performance, which suggests that there may be space to resist ruling party directives.

Once again, while our survey focuses on attitudes that are likely linked to behavior, bureaucrats' attitudes are important in their own right. If bureaucrats are resistant to the political use of funds and yet are powerless to act in accordance, they are likely to be demotivated, putting less effort into their work. Such shirking could inadvertently undermine the political use of resource revenue. As such, bureaucrats need not always actively obstruct

\footnotetext{
${ }^{28}$ We do not have comparable measures in Ghana because of differences in the survey questionnaires.

${ }^{29}$ The proportion of respondents reporting each type of attitude is roughly equivalent in each country.
} 
political directives for them to prevent political spending of oil revenue.

\subsection{Survey Sample and Logistics}

We conducted the survey with central government employees whose primary work location is in the capital city of each country. We excluded both local government employees and "street-level" bureaucrats such as teachers, nurses, doctors, bus drivers, and police to exclude those who have no experience engaging with resource revenues. To ensure a diverse sample, we included employees across a range of organizations, functions, levels of employment and contract-types. ${ }^{30}$ Our survey sample is based primarily on access and convenience given the absence of an accurate government employee register, with an effort to stratify the sample in a general sense across public service institutions. ${ }^{31}$

We estimate the size of this population of Ghanaian bureaucrats using the "Analysis of Staff Strength" from Ghana's Ministry of Finance and Economic Plannings (MOFEP) 2017 Budget Statement Appendix. Our calculations in Appendix E suggest an estimated population of 97,655 public service employees. With 1,641 survey respondents, this means our sample constitutes an estimated $1.7 \%$ of the population.

The 2017 Uganda Statistical Abstract, which is produced annually by the Uganda Bureau of Statistics reports that the size of the "traditional civil service" (which excludes the teaching service, police and prisons, public universities, and local governments) at 22,965 in 2016 (Uganda Bureau of Statistics, 2017). We take this number and adjust for the growth in the public service and the inclusion of agency employees in our sample; see Appendix E. Given our calculations, our sample of 1,537 represents roughly $3.3 \%$ of the 47,170 estimated population at the time of the survey.

Both surveys were conducted by local enumerators in 2017. We reached bureaucrats

\footnotetext{
${ }^{30}$ We recognize that not all institutions are likely to manage or receive oil revenues, thereby dampening any potential effects from oil revenue. In response, we also conducted a test of Hypothesis 1 with a sample restricted to those institutions that have (or will) plausibly receive oil revenue, and found similar effects.

${ }^{31}$ There are significant logistical challenges involved in obtaining a random sample of public officials in African countries, many of which have an uncertain and ever-changing population of government officials, and incomplete registers of public employment.
} 
from a total of 49 different institutions in Ghana and 31 in Uganda. The list of institutions are provided in Appendix D. Demographic statistics for the survey sample are provided in Table 1. The two country samples are roughly equivalent in a number of key areas that make comparisons across the two samples reasonable. Both samples have at least $80 \%$ with bachelors degrees, equal average years in the service, and nearly identical average ages. We also see roughly the same breakdown of managers, technical/professional staff, and administrators, which suggests that differences across the samples in terms of outcomes are not likely driven by different types of bureaucrats in each sample. ${ }^{32}$

Table 1: Survey Sample Demographics

\begin{tabular}{lcc}
\hline \hline & Ghana & Uganda \\
\hline Number of Respondents & 1641 & 1537 \\
\% Female & $46.9 \%$ & $45.0 \%$ \\
\% with Bachelors degree or higher & $80.1 \%$ & $85.2 \%$ \\
Average Years of Service & 10.9 & 10.9 \\
Average Age & 38.1 & 37.4 \\
\% Largest Ethnic Group (Ashante/Baganda) & $17.4 \%$ & $29.8 \%$ \\
Role/Position & & \\
\% Manager & $11.7 \%$ & $13.7 \%$ \\
\% Technical/Professional & $39.9 \%$ & $46.4 \%$ \\
\% Administrative & $47.5 \%$ & $39.3 \%$ \\
Partisanship & & \\
Support/Member of Party & $31.0 \%$ & $36.5 \%$ \\
Non-Partisan & $50.8 \%$ & $47.6 \%$ \\
Prefer Not to Respond & $18.2 \%$ & $15.9 \%$ \\
Ruling Party Supporter & $18.9 \%$ & $24.2 \%$ \\
Opposition Party Supporter & $7.6 \%$ & $13.4 \%$ \\
\hline
\end{tabular}

In order to test if the random assignment to treatment is balanced on observables, we regress treatment status on a number of covariates. We find that treatment status is not predicted by being affiliated with a political party, concern that the ruling party will disapprove

\footnotetext{
${ }^{32}$ Managers are classified as anyone who indicated in the survey that one of their job responsibilities is to "supervise other public servants". Technical/professional staff are those that are not primarily managers and who provide technical or professional services such as program design, planning or budgeting. Administrative assistants are those who provide administrative support for the day-to-day running of the various offices across the public service.
} 
of one's work (Fear of the Ruling Party), perceptions of corruption in one's organization, being a manager, one's salary, years in the public service, education, age, or gender (see Table 15 in Appendix F). We can therefore be relatively confident that the treatment was in fact randomly assigned.

\section{Results}

We divide the analysis into five parts corresponding to each of the five hypotheses. The first part examines overall differences in responses to the outcome question across treatment and control groups as outlined in Hypothesis 1. We also report analyses of the placebo treatment. The placebo analysis informs us if any observed effects might be driven by more generic increases in government revenue rather than oil revenue in particular. Subsequently, we assess our hypotheses that certain types of bureaucrats react differently to oil revenue. In Section 5.2, we assess subgroup differences for job security (Hypothesis 2). In section 5.3 we consider differing effects according to partisan affiliation (Hypothesis 3). Then, in Section 5.3, we test the patronage network hypothesis (Hypothesis 4), and in Section 5.4 we test whether those with higher levels of public service motivation are more likely to disagree with directing revenue to political supporters when treated with the oil revenue prime (Hypothesis $5)$.

All results presented in this section are based on two-tailed difference-of-means tests comparing average levels of agreement with the statement about spending in politicallysupportive districts. ${ }^{33}$ Positive differences reflect the treatment group expressing higher levels of agreement with the statement, and therefore greater evidence of them acting as agents of the ruling party. Negative differences imply that treated respondents disagree more with the statement about directing spending to politically supportive districts, and are therefore more likely to oppose ruling party directives.

\footnotetext{
${ }^{33}$ For robustness, we subject all statistically significant results to non-parametric tests, the results of which are presented in Appendix I.
} 


\subsection{Oil Revenue and Bureaucratic Compliance}

We first test Hypothesis 1 stating that bureaucrats learning about oil revenue will be more likely to agree with the ruling party's right to channel revenue to politically supportive districts. Table 2 presents results for comparing mean responses between the treatment and control groups across the two countries. In Ghana, treatment with the oil revenue prime has a negative, but not statistically significant effect on level of agreement with the statement. The effect in Uganda is also negative but, unlike Ghana, the difference is larger and statistically significant at the $10 \%$ level $(p=0.06) .{ }^{34}$ This means that when respondents in Uganda learn that the government will receive greater revenue from oil, their level of agreement with the statement decreases. $^{35}$

Table 2: Hypothesis 1

\begin{tabular}{lrrrrrr}
\hline \hline & $\begin{array}{c}\text { Uganda } \\
\text { Treatment } \\
(\mathrm{N})\end{array}$ & $\begin{array}{c}\text { Control } \\
(\mathrm{N})\end{array}$ & Diff. & $\begin{array}{c}\text { Ghana } \\
\text { Treatment } \\
(\mathrm{N})\end{array}$ & $\begin{array}{c}\text { Control } \\
(\mathrm{N})\end{array}$ & Diff. \\
\hline Full Sample & .45 & .58 & $-.13^{*}$ & .61 & .66 & -.05 \\
& $(516)$ & $(503)$ & & $(539)$ & $(512)$ & \\
\hline \hline
\end{tabular}

Two-tailed difference-of-means tests. ${ }^{*} \mathrm{p}<.1{ }^{* *} \mathrm{p}<.05$

To test the effect of the placebo, we conduct difference-of-means tests between the control group and three versions of the placebo sample. In the first test, the placebo sample is composed of all respondents assigned to the placebo group. Second, we exclude respondents who associated government revenue exclusively with oil, meaning they did not mention any other revenue sources besides oil when responding to the manipulation check that asked them what was the likely source of the mentioned revenue increase (Placebo Restricted 1).

\footnotetext{
${ }^{34}$ In Section 5.6, we address in more detail potential explanations for country-level differences found here and in Sections 5.2-5.5.

${ }^{35}$ The results are similar when we restrict the sample to include only bureaucrats in institutions that have (Ghana), or will (Uganda), plausibly see oil money. We determine the sectors potentially receiving oil revenue using Ghana's reports on oil revenue spending according to reports on the Annual Budget Funding Amount (ABFA) available at http://www.piacghana.org/portal/29/36/the-abfa, and Uganda's Oil and Gas Revenue Management Policy available at http://www.acode-u.org/Files/oildocs/Oil_Revenue_ Mgt_Policy.pdf. There are again no differences between treatment and control groups in Ghana. There are negative effects in Uganda, but the effects are not statistically significant, likely because the sample size declines to 298 total bureaucrats.
} 
In the third test, we exclude those who associated the message with oil regardless of any other sources of revenue they may have identified (Placebo Restricted 2). For those who associate the placebo revenue source with oil, we believe that the placebo condition acts as the treatment condition, therefore warranting their exclusion. The results are displayed in Table 3 .

The placebo message has no clear effect in Ghana. A placebo effect is evident in Uganda, but it is of lower magnitude (especially in the cleanest case: 'Restricted Sample 1') than the treatment effect and does not achieve statistical significance when restricted to those in the placebo group who passed the manipulation check. We interpret these results to mean that generic increases in government revenue may induce bureaucrats to oppose ruling party efforts to spend government funds in politically advantageous ways, but that the effect is slightly larger and more consistent for oil revenue in particular, a finding consistent with ideas put forward by Ross (2015).

Table 3: Placebo Analysis

\begin{tabular}{lrrrrrr}
\hline \hline & $\begin{array}{c}\text { Uganda } \\
\text { Treatment } \\
(\mathrm{N})\end{array}$ & $\begin{array}{c}\text { Control } \\
(\mathrm{N})\end{array}$ & $\begin{array}{c}\text { Ghana } \\
\text { Diff. } \\
\text { Treatment } \\
(\mathrm{N})\end{array}$ & $\begin{array}{c}\text { Control } \\
(\mathrm{N})\end{array}$ & Diff. \\
\hline Placebo Analysis & & & & & & \\
\hline Full Sample & .46 & .58 & $-.12^{*}$ & .67 & .66 & .02 \\
Exclude Those Who & $(485)$ & $(503)$ & & $(557)$ & $(512)$ & .007 \\
Associate with ONLY Oil & .48 & .58 & -.10 & .66 & .66 & .007 \\
Exclude Those Who & $(440)$ & $(503)$ & & $(535)$ & $(512)$ & .10 \\
Associate with ANY Oil & $(315)$ & $(503)$ & & $(294)$ & $(512)$ & \\
\hline \hline
\end{tabular}

Two-tailed difference-of-means tests. ${ }^{*} \mathrm{p}<.1 * * \mathrm{p}<.05$

To further probe the observed effects in Uganda, we explore differences in the specific response categories for the treatment and control groups. Table 4 shows these differences. It is clear that the effect of the treatment was strongest at the lowest levels of agreement (the frequency of the Strongly Disagree response is $5.52 \%$ higher for the treatment group), with smaller decreases in each of the three middle categories, and virtually the same level of response for those that strongly agree with the statement about directing funds to ruling 
party supporters. The oil revenue treatment is 'moving' those who might otherwise be more ambivalent towards the political use of resources to more strongly disagree with the statement. Contrary to the expectations outlined in Hypothesis 1, the prime appears to induce a concern on the part of bureaucrats that politicians will use oil revenue to favor their political supporters and/or further entrench their power.These results provide initial evidence to suggest that ruling parties may in fact face a principal-agent problem when seeking to use oil revenues for political purposes.

Table 4: Differences by Response Category in Uganda

\begin{tabular}{lccc}
\hline \hline Response & Control & Treatment & Difference \\
\hline Strongly Disagree & $73.16 \%$ & $78.68 \%$ & $+5.52 \%$ \\
Somewhat Disagree & $12.13 \%$ & $10.66 \%$ & $-1.47 \%$ \\
Neither Agree nor Disagree & $3.18 \%$ & $2.33 \%$ & $-0.85 \%$ \\
Somewhat Agree & $6.56 \%$ & $3.29 \%$ & $-3.27 \%$ \\
Strongly Agree & $4.97 \%$ & $5.04 \%$ & $+0.07 \%$ \\
\hline
\end{tabular}

An alternative interpretation of these results might be a social desirability one. It is possible that respondents are 'spooked' by the prime and react more strongly when primed with oil in accordance with a perceived 'proper' behavior of denouncing the political use of funds. As we demonstrate below, however, it is not those who are affiliated with the ruling party who have this reaction, ${ }^{36}$ giving us little reason to think that social desirability bias accounts for our findings. Further, in Appendix M, we use list experiment data from elsewhere in the survey to infer the degree to which social desirability bias may be present when bureaucrats are asked about diverting funds for political use, and the evidence suggests that social desirability bias is not a major concern.

\footnotetext{
${ }^{36}$ We would expect ruling party supporters to be more susceptible to social desirability bias given that it is their party that would be diverting funds.
} 


\section{$5.2 \quad$ Job Security}

Hypothesis 2 suggests that those who feel more secure in their jobs would be more likely to oppose political leaders' efforts to direct resource revenue to political supporters because retention of their jobs may be less tied to complying with political spending directives. In order to test this hypothesis we construct a measure of job security using responses from two survey questions measuring the extent to which respondents feel secure in their jobs. The questions ask respondents to rate their level of agreement (1-5) with the following statements: 1) "I expect to spend the rest of my career in the public service" and 2) "It would be difficult to dismiss me from the public service". We take the average of the two responses and divide the resulting index at its median to create two groups: a group with higher levels of job security and another group with lower levels of job security.

The results, displayed in Table 5 , show that effects of the oil treatment are considerably larger among those who feel more secure in their jobs in the public service. The effect is also negative among those who feel less secure, but it is considerably smaller and does not achieve conventional standards of statistical significance. This result confirms that those who are more secure in their job are less likely to agree with the political use of funds when primed with oil windfalls. ${ }^{37}$

Table 5: Hypothesis 2

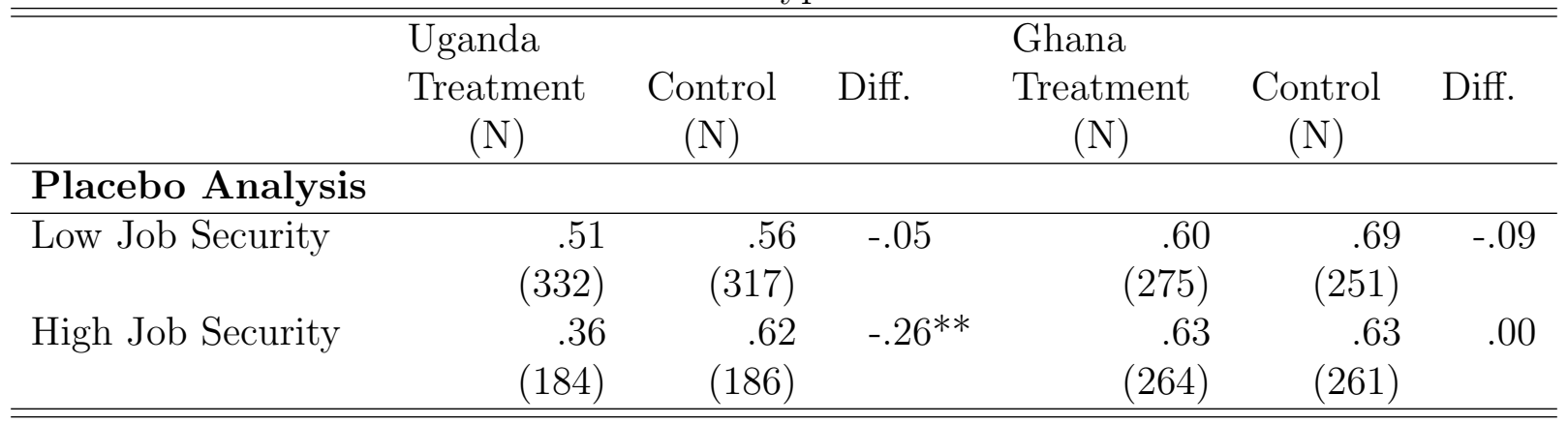

Two-tailed difference-of-means tests. ${ }^{*} \mathrm{p}<.1{ }^{*} \mathrm{p}<.05$

\footnotetext{
${ }^{37}$ In Appendix K we estimate ordered logit regressions that use an interaction term between our continuous measure of job security and the treatment. We do the same for our continuous measure of networks. The results are robust in both cases.
} 


\subsection{Partisan Affiliation}

In this section we test Hypothesis 3 by examining whether respondents who are not supporters of the ruling party are more likely to express disagreement with the statement about political use of revenue when primed. To measure partisan support, we use two questions from the survey. The first question asks respondents if they support or are a member of a political party. If the respondent answered yes to either of these, then they received a followup question asking them which party they support. Descriptive statistics for responses to these questions are provided in Table 1 above. Due to the low number of respondents, likely due to bias, who identify with opposition parties (13.4\% in Uganda and $7.6 \%$ in Ghana), we are not able to effectively compare those who affiliate with the ruling party with those who affiliate with opposition parties. For this reason we compare ruling party supporters to non-ruling party supporters - a group that includes both those who indicated that they support or are a member of an opposition party, and those who support no party at all.

Table 6 shows results of the tests of Hypothesis 3. As expected those who do not support the ruling party are, when treated with the oil revenue prime, more likely to disagree with the statement. ${ }^{38}$ Given the limitations of our partisanship measure, we can not conclusively state whether those in the "Non-Ruling Party" group are driven by political or other motivations, but the following two tests of Hypotheses 4 and 5 provide some clues in this regard.

Table 6: Hypothesis 3

\begin{tabular}{|c|c|c|c|c|c|c|}
\hline & \multicolumn{3}{|l|}{ Uganda } & \multicolumn{3}{|l|}{ Ghana } \\
\hline & $\begin{array}{l}\text { Treatment } \\
(\mathrm{N})\end{array}$ & $\begin{array}{l}\text { Control } \\
(\mathrm{N})\end{array}$ & Diff. & $\begin{array}{l}\text { Treatment } \\
(\mathrm{N})\end{array}$ & $\begin{array}{l}\text { Control } \\
(\mathrm{N})\end{array}$ & Diff. \\
\hline Ruling Party & $\begin{array}{r}.56 \\
(94)\end{array}$ & $\begin{array}{r}.62 \\
(114)\end{array}$ & -.06 & $\begin{array}{r}.60 \\
(73)\end{array}$ & $\begin{array}{r}.67 \\
(63)\end{array}$ & -.06 \\
\hline Non-Ruling Party & $\begin{array}{r}.38 \\
(336)\end{array}$ & $\begin{array}{r}.57 \\
(288)\end{array}$ & $-.19^{* *}$ & $\begin{array}{r}.63 \\
(351)\end{array}$ & $\begin{array}{r}.58 \\
(318)\end{array}$ & -.05 \\
\hline
\end{tabular}

Two-tailed difference-of-means tests. ${ }^{*} \mathrm{p}<.1{ }^{* *} \mathrm{p}<.05$

\footnotetext{
${ }^{38}$ It is also worth noting that ruling party supporters in both the treatment and control groups start with a statistically significant higher level of agreement (approximately .63 on a 0-4 scale) compared to those who do not support the ruling party (.35 on a $0-4$ scale).
} 
In both countries we find null treatment effects for those who identify with the ruling party. By contrast, in Uganda, those receiving the treatment who are not affiliated with the ruling NRM, including both non-partisans and opposition supporters, are significantly $(p=.03)$ more likely to have a higher level of disagreement with the statement about the political use of revenue than those in the control group. Importantly, in Uganda, the effect size for non-ruling party is more than three times the size of that for the ruling party. These findings suggest that those not supporting the ruling NRM are, consistent with Hypothesis 3, less supportive of directing oil revenue than those who are supportive of the ruling party. Importantly, these results also suggest that this is not a case of NRM supporters becoming 'spooked' by a controversial topic and over-compensating by more strongly disagreeing with the statement.

\subsection{Patronage Networks}

Whether they are co-partisans with the ruling party or not, bureaucrats may or may not benefit from the government's patronage. Here we test Hypothesis 4, which states that those outside the government's patronage network may be more likely to oppose the ruling party's efforts to direct resource revenues to political supporters. We do so by constructing a measure of an individual bureaucrat's "connectedness" to people empowered to help them in their career using responses to six questions (listed in Appendix G) asking about the importance of personal and political connections in obtaining one's job, a promotion, or a salary raise. All questions are measured on a 1-7 scale where 1 represents "not at all important" and 7 represents "very important". 39 To aggregate, we code those who answered 2 or above to any of the six questions as "connected". ${ }^{40}$ As stated in Hypothesis 4, we expect those attributing

\footnotetext{
${ }^{39}$ We use direct questions about personal and political links given that the analyses in Appendix M do not suggest our results are driven by social desirability bias.

${ }^{40}$ Those results suggest that those lacking personal (friends or family) links to help them in their jobs are particularly sensitive to the treatment. Note also that levels of connectedness vary considerably across the two countries, with individuals in Ghana according more importance to personal connections, in particular, that have helped them in their careers. In Uganda, connections tend to be more political in nature. This measure of connectedness correlates with expressed ruling party affiliation at .174 in Uganda and .057 in
} 
less importance to their personal and political connections to, when treated, disagree more strongly with the statement about political spending since these individuals would be less likely to benefit. The results are presented in Table $74^{41}$

Table 7: Hypothesis 4

\begin{tabular}{|c|c|c|c|c|c|c|}
\hline & $\begin{array}{l}\text { Uganda } \\
\text { Treatment } \\
(\mathrm{N})\end{array}$ & $\begin{array}{l}\text { Control } \\
(\mathrm{N})\end{array}$ & Diff. & $\begin{array}{l}\text { Ghana } \\
\text { Treatment } \\
(\mathrm{N})\end{array}$ & $\begin{array}{l}\text { Control } \\
(\mathrm{N})\end{array}$ & Diff. \\
\hline \multicolumn{7}{|l|}{ Hypothesis 4} \\
\hline Connected & $\begin{array}{r}.69 \\
(182)\end{array}$ & $\begin{array}{r}.71 \\
(180)\end{array}$ & -.02 & $\begin{array}{r}.79 \\
(340)\end{array}$ & $\begin{array}{r}.80 \\
(304)\end{array}$ & -.01 \\
\hline Not Connected & $\begin{array}{r}.33 \\
(332)\end{array}$ & $\begin{array}{r}.51 \\
(322)\end{array}$ & $-.18^{* *}$ & $\begin{array}{r}.31 \\
(197) \\
\end{array}$ & $\begin{array}{r}.41 \\
(199)\end{array}$ & -.10 \\
\hline \multicolumn{7}{|l|}{$\begin{array}{l}\text { Non-Ruling Party } \\
\text { Only: }\end{array}$} \\
\hline Connected & $\begin{array}{r}.61 \\
(106)\end{array}$ & $\begin{array}{r}.60 \\
(87)\end{array}$ & .02 & $\begin{array}{r}.81 \\
(215)\end{array}$ & $\begin{array}{r}.75 \\
(180)\end{array}$ & .06 \\
\hline Not Connected & $\begin{array}{r}.28 \\
(229) \\
\end{array}$ & $\begin{array}{r}.56 \\
(201) \\
\end{array}$ & $-.28^{* * *}$ & $\begin{array}{r}.35 \\
(135) \\
\end{array}$ & $\begin{array}{r}.34 \\
(135) \\
\end{array}$ & .01 \\
\hline
\end{tabular}

Two-tailed difference-of-means tests. ${ }^{*} \mathrm{p}<.1{ }^{* *} \mathrm{p}<.05$

The results provide support for the hypothesis that those who do not benefit from patronage are, when treated with the oil prime, significantly less likely to agree with statements condoning greater spending in politically supportive districts $(p=.02)$. Consistent with previous results however, evidence supporting the hypothesis is only found in Uganda. Further, the negative-valued difference is greater when the sample is restricted to non-NRM supporters, suggesting that those who are not affiliated with the ruling party and outside of patronage networks are most likely to oppose ruling party efforts to use oil revenue to their political advantage.

\section{Ghana.}

${ }^{41}$ In Appendix 18, we present results of t-tests for these groups in Uganda disaggregated based on their responses to each of the six survey questions. The results from the disaggregated models suggest that those not having personal networks - friends and family - that help them in their careers are particularly sensitive to the treatment. 


\subsection{Public Service Motivation}

Finally, bureaucrats may oppose ruling party efforts to direct resource revenue to political supporters because of strong public service values, as explained in Hypothesis 5. We test this hypothesis by examining heterogeneity in the treatment effects across subgroups of bureaucrats with different levels of public service motivation. We expect those with higher levels of public service motivation to have interests that diverge from the political use of oil rents. On the other hand, bureaucrats with private and/or material motivations, such as those concerned with job security or lack of access to patronage networks, would be more likely to act in accordance with the ruling party, particularly when the ruling party has access to oil revenue, and hence more patronage to offer.

To test this hypothesis, we construct an index of public service motivation using a basic principal components model to aggregate responses to sixteen attitudinal questions commonly used to measure public service motivation (Kim et al., 2012). The indicators include, for example, one's commitment to public values and compassion and willingness to sacrifice for others. The full list of questions are provided in Appendix H. Responses to all questions are measured on a five point scale ranging from strongly disagree (1) to strongly agree (5). We divide the index at its median and compare the effects of the prime treatment across the two subgroups - those with relatively high and relatively low levels of public service motivation.

Table 8: Hypothesis 5

\begin{tabular}{lrrrrrr}
\hline \hline & $\begin{array}{c}\text { Uganda } \\
\text { Treatment } \\
(\mathrm{N})\end{array}$ & $\begin{array}{c}\text { Control } \\
(\mathrm{N})\end{array}$ & Diff. & $\begin{array}{l}\text { Ghana } \\
\text { Treatment } \\
(\mathrm{N})\end{array}$ & $\begin{array}{c}\text { Control } \\
(\mathrm{N})\end{array}$ & Diff. \\
\hline Hypothesis 5 & & & & & & \\
\hline Low PSM & .62 & .79 & -.17 & .80 & .88 & -.07 \\
& $(247)$ & $(253)$ & & $(268)$ & $(248)$ & \\
High PSM & .30 & .37 & -.07 & .42 & .45 & -.03 \\
& $(269)$ & $(250)$ & & $(271)$ & $(264)$ & \\
\hline \hline
\end{tabular}


The results, displayed in Figure 8, show that there is not sufficient evidence to support the hypothesis that those with greater levels of public service motivation (PSM) would be more likely to oppose political leaders' efforts to direct spending to their political supporters when learning about oil revenue increases.

To assess the robustness of these null effects, we also test differences in treatment effects using a behavioral measure of pro-sociality in Uganda. At the end of the survey, respondents were asked to donate to one of three charities. We assume that those who donated should also be more pro-social and thus more public service oriented. We find no differential effect of the treatment among those who do and do not donate part of their survey compensation to charity (see Appendix L for this analysis). This finding further suggests that differences in public service motivation are not driving the observed effects.

\subsection{Discussion}

The results presented above underscore the importance of studying principal-agent problems encountered by political leaders and bureaucrats in contexts with recent oil discoveries, early oil extraction, and anticipated oil production. Contrary to Hypothesis 1 and the unitary state assumption underlying the resource curse literature, bureaucrats may not always see themselves as agents of the ruling party in facilitating political uses of oil revenue. In fact, we find that respondents in one of our cases, Uganda, who receive information about oil revenue are more likely to disagree with a statement about the political use of government revenue. We show that these results are not likely to be driven by social desirability bias. Instead, they reflect respondents' concerns about the ruling party's potential use of new revenue, and especially oil revenue, to further entrench their power.

The findings also provide clear evidence about the types of bureaucrats who are likely (in Uganda) to oppose ruling party efforts to use oil revenue for political advantage. Specifically, the evidence in Uganda suggests that those who are more secure in their jobs, unaligned with the ruling party, and outside of government patronage networks are more likely to 
express disagreement with the ruling party's political use of oil revenue. Together, these results suggest the importance of material and political motivations in understanding why bureaucrats may oppose political leaders' spending strategies.

Finally, we find no evidence to support the notion, expressed in Hypothesis 5, that some bureaucrats may seek to obstruct ruling party rentierism in efforts to safeguard the public interest.

\section{Country-Level Differences}

Across all tests, the results are substantively different in Ghana and Uganda. While we cannot comfortably adjudicate explanations for country-level differences, we briefly return to the three potentially relevant country differences discussed in Section 3. First, and perhaps most critically, the competitive political context in Ghana may be more amenable to citizen or opposition monitoring, thus constraining politicians in their ability to press for the political benefits of oil revenue such that bureaucrats need not concern themselves with non-compliance. Indeed, the legal provisions in Ghana surrounding the use of oil revenue are monitored by a coalition of civil society groups who remain independent from the government. Given the strength of Ghana's opposition, any egregious misuse of oil revenue or widespread sanctioning of bureaucrats based on non-compliance, is likely to come to light and affect the ruling party's electoral fortunes.

Another important political factor, discussed in Appendix C, is that the Ugandan bureaucrats surveyed were about twice as likely as Ghanaians to report that they had been hired with the help of a politician or had helped divert public resources to parties or politicians, suggesting that Ugandan politicians may have greater control over bureaucrats and an enhanced ability to the use the state for political advantage. Though only suggestive, this difference might explain why Ugandan civil servants have, on average, greater levels of concern about the potential for the ruling party to use resource revenues in ways that will further entrench their power and further increase their control. 
Second, economic differences between the two countries may be at play. For example, the higher level of wealth and historic experience with resource exports in Ghana means that the effects of oil are simply not felt as strongly as they would be in Uganda. Likewise, it is possible, given Ghana's higher level of wealth, that increases in spending in politically supportive districts may not displace spending in other districts to the extent that it would in the less wealthy context of Uganda.

Finally, the different stages of oil production may contribute to differences in countrylevel results. Either through direct experience in implementation or observations as citizens, some Ghanaian bureaucrats may have observed that politically-directed spending has not changed significantly since oil production began. Since Ugandan bureaucrats have no actual observations of oil revenue on which to base their experiences, they may be anticipating a negative effect of oil revenue. Our experience conducting this research indicates that Ugandans are keenly aware of the potential pitfalls associated with oil revenue and want to avoid becoming another Nigeria, a country notorious for the resource curse.

While merely speculative, these differences do suggest important avenues for future research, particularly concerning the role of existing political, bureaucratic and economic structures. In other words, it is necessary to move beyond move beyond unitary state assumptions in the literature on the resource curse and explore how existing institutional configurations within the state shape processes of rentierization.

\section{Conclusion}

Although most previous work on the resource curse has largely assumed away the role of bureaucrats, our findings suggest that this is an important population to study to better understand when and how political leaders are likely to pursue the spending strategies that commonly lead to both political and economic manifestations of the resource curse. The findings presented here illustrate in particular the need to revisit the "unitary state" as- 
sumptions underlying much of the literature on the political economy of the resource curse. Political leaders in oil-rich countries are not necessarily immune to the principal-agent problems commonly associated with politician-bureaucrat relationships throughout the world. In this section we identify several important takeaways and suggest avenues for further analysis.

First, we find little support for the idea that bureaucrats will become more politicized, at least in the short term, in the face of new resource extraction. Instead, it appears, that at least some bureaucrats will have an especially strong reaction against the use of oil revenue for political purposes. This finding has important policy implications for donors and organizations working on natural resource revenue management. In particular, we identify a potential population of bureaucrats - those who enjoy high job security, are not supporters of the ruling party, and/or who are outside patronage networks - who may be interested in holding the government accountable for its use of natural resource revenue. One important question for future research is how long after revenue extraction bureaucrats oppose the political use of oil revenue.

Second, we find that effects of resource revenues on the political use of public resources vary considerably across the two countries. These findings add to recent research suggesting that effects of resource wealth may be contextually contingent (Haber and Menaldo, 2011; Dunning, 2008). However, the presence of obstructionist-oriented bureaucrats in Uganda and their apparent absence in Ghana suggests that the democratic-authoritarian divide in terms of context is likely too coarse to understand differences in how bureaucrats react to revenue windfalls. Instead, understanding bureaucrats' reactions to revenue windfalls requires a deeper investigation into the factors that drive bureaucrats to serve or oppose ruling party directives, and the specific levers of control politicians possess.

A third point is that future research ought also to consider the longer-term effects of bureaucratic compliance or resistance. With the introduction of new resource revenue, initial responses of state agents may shape the ease or difficulty with which political leaders are able to channel resource revenues to their political supporters. In the longer term, such dy- 
namics may shape how rulers use and manage the bureaucracy. Where politicians encounter principal-agent problems, they may resort to alternative strategies to entrench their political advantage or seek to change the political composition of the bureaucracy. How and under what circumstances these processes unfold is critical for advancing knowledge on processes and mechanisms through which the resource curse takes hold.

Fourth, that public service values do not seem to influence bureaucrats' willingness to facilitate or obstruct rentierism further challenges prevailing theories about when and why rentierization is more or less likely to occur. This finding implies that bureaucratic selfinterest may potentially have a silver lining: if bureaucrats perceive unfair advantages for better-connected colleagues, they may seek to prevent their further marginalization. Is it possible that such bureaucrats could be a vehicle for change? This remains to be seen and is another important line of questioning for future research.

As the first study of its kind, we have, naturally, also discovered some of the challenges and limitations involved in research on bureaucrats in states with large oil windfalls. Perhaps most critically, a more robust understanding of attitudinal and institutional changes associated with the resource extraction will require observations over time. With only a snapshot, we are ultimately limited in understanding how the observed attitudinal patterns do or do not translate into behavior and how, more broadly, these dynamics shape the trajectory of institutions in new oil producing states. Future theoretical and empirical work could also more fully account for the varieties of bureaucratic and political actors involved in the political use of resource revenues - for instance by theorizing relationships between high- and low-level bureaucrats as well as other within-government relationships. Finally, much could be gained by more fully delineating differential effects of increases in generic revenue versus oil or resource revenue. All of these areas represent promising areas for future innovation.

Despite these challenges, this study sheds important light on several key dimensions of bureaucracies that can shape whether politicians in resource-rich contexts face principalagent problems in pursuit of their political spending strategies. In addition, our findings 
provide nascent insight into the varying governance outcomes that may result from the wave of oil and gas discoveries in sub-Saharan Africa and beyond. Bureaucrats who are not affiliated with the ruling party and do not benefit from current patronage systems may have a particularly important role to play in shaping the patterns of governance that arise in the wake of incipient oil production. As our findings indicate, this group in particular may oppose ruling party exploitation and indelibly shape the trajectories of new oil-producing states. 


\section{References}

Anderson, Lisa (1987). The state in the middle east and North Africa. Comparative Politics 20(1), $1-18$.

Atkinson, Giles and Kirk Hamilton (2003). Savings, growth and the resource curse hypothesis. World development 31(11), 1793-1807.

Auty, Richard M (1994). Industrial Policy Reform in Six Large Newly Industrializing Countries: The resource curse thesis. World Development 22(1), 11-26.

Badeeb, Ramez, Hooi Hooi Lean, and Jeremy Clark (2017). The evolution of the natural resource curse thesis: A critical literature survey. Resources Policy 51(C), 123-134.

Blair, Greame and Kosuke Imai (2012). Statistical Analysis of List Experiments. Political Analysis $20,47-77$.

Brierley, Sarah (2016). Unprincipled Principals: Co-opted Bureaucrats and Corruption in Local Governments in Ghana.

Caselli, Francesco and Tom Cunningham (2009). Leader behaviour and the natural resource curse. Oxford Economic Papers 61(4), 628-650.

Caselli, F. and G. Michaels (2013). Do oil windfalls improve living standards? Evidence from Brazil. American Economic Journal Applied Economics 5(1), 208-238.

Chaudhry, Kiren Aziz (1997). The Price of Wealth: Economies and Institutions in the Middle East. Cornell University Press.

Chen, Chung-An and Chih-Wei Hsieh (2015). Does Pursuing External Incentives Compromise Public Service Motivation? Comparing the effects of job security and high pay. Public Management Review 17(8), 1190-1213.

Collier, Paul and Anke Hoeffler (1998). On Economic Causes of Civil War. Oxford Economic Papers 50, 563-573. 
Cotet, A and KK Tsui (2013). Oil and Conflict: What Does the Cross Country Evidence Really Show? American Economic Journal Macroecon 5(1), 49-80.

Crewson, Philip E (1997). Public-service motivation: Building empirical evidence of incidence and effect. Journal of public administration research and theory 7(4), 499-518.

Croese, Sylvia (2017). State-Led Housing Delivery as an Unstrument of Developmental Patrimonialism: The Case of Post-War Angola. African Affairs 116(462), 80-100.

Dahlström, Carl, Jan Teorell, Stefan Dahlberg, Felix Hartmann, Annika Lindberg, and Marina Nistotskaya (2015). The QoG Expert Survey Dataset II. Quality of Government Institute, Univeristy of Gothenburg.

Dauvin, Magali and David Guerreiro (2017). The Paradox of Plenty: A meta-analysis. World Development 94, 212-231.

de la Cuesta, Brandon, Helen V. Milner, Daniel L. Nielson, and Stephen Knack (2017, July). Taxation without Representation? Experimental Evidence from Ghana and Uganda on Citizen Action toward Taxes, Oil, and Aid. World Bank Policy Research Working Paper.

De Sardan, JP Olivier (1999). A moral economy of corruption in Africa? the Journal of Modern african Studies 37(1), 25-52.

Dunning, Thad (2008). Crude democracy: Natural resource wealth and political regimes, Volume 7. Cambridge University Press Cambridge.

Finer, Herman (1941). Administrative Responsibility in Democratic Government. Public administration review 1(4), 335-350.

Foltz, Jeremy D and Kweku A Opoku-Agyemang. Do higher salaries lower petty corruption? A policy experiment on West Africas highways. Unpublished Manuscript.

Frank, Sue A and Gregory B Lewis (2004). Government employees: Working hard or hardly working? The American Review of Public Administration 34(1), 36-51. 
Frankel, Jeffrey A (2010). The Natural Resource Curse: A Survey. Technical report, National Bureau of Economic Research.

Gailmard, Sean and John W Patty (2007). Slackers and zealots: Civil service, policy discretion, and bureaucratic expertise. American Journal of Political Science 51(4), 873-889.

Gingerich, Daniel W (2013). Political institutions and party-directed corruption in South America: Stealing for the team. Cambridge University Press.

Government of Ghana (2015, November). The Budget Statement and Economic Policy of the Government of Ghana for the 2016 Financial Year. Report Presented in Parliament.

Government of Uganda (2012, February). Oil and Gas Revenue Management Policy. http://www.acode-u.org/Files/oildocs/Oil_Revenue_Mgt_Policy.pdf.

Grindle, Merilee S (2012). Jobs for the Boys. Cambridge: Harvard University Press.

Haber, Stephen and Victor Menaldo (2011). Do Natural Resources Fuel Authoritarianism? A Reappraisal of the Resource Curse. American Political Science Review 105(1), 1-26.

Hassan, Mai and Thomas O'Mealia (2018). Uneven Accountability in the Wake of Political Violence: Evidence from Kenyas Ashes and Archives. Journal of Peace Research 55(2), 161-174.

Herbst, Jeffrey (1999). States and power in Africa: Comparative lessons in authority and control. Princeton: Princeton University Press.

Hertog, Steffen (2010). Princes, Brokers, and Bureaucrats: Oil and the State in Saudi Arabia. Cornell University Press.

Hickey, Sam, Abdul-Gafaru Abdulai, Angelo Izama, and Giles Mohan (2015). The Politics of Governing Oil Effectively: A comparative study of two new oil-rich states in Africa.

Houston, David J (2000). Public-Service Motivation: A multivariate test. Journal of public administration research and theory 10(4), 713-728. 
Huber, John D and Nolan McCarty (2004). Bureaucratic Capacity, Delegation, and Political Reform. American Political Science Review 98(3), 481-494.

Huntington, Samuel P (1968). Political order in changing societies. New Haven: Yale University Press.

Johnson, Martha C (2015). Donor Requirements and Pockets of Effectiveness in Senegal's Bureaucracy. Development Policy Review 33(6), 783-804.

Karl, Terry Lynn (1997). The Paradox of Plenty: Oil Booms and Petro-States, Volume 26. University of California Press.

Khanna, Arpita Asha (2017). Revisiting the Oil Curse: Does Ownership Matter? World Development 99, 214-229.

Kim, Sangmook, Wouter Vandenabeele, Bradley E Wright, Lotte Bøgh Andersen, Francesco Paolo Cerase, Robert K Christensen, Céline Desmarais, Maria Koumenta, Peter Leisink, Bangcheng Liu, et al. (2012). Investigating the Structure and Meaning of Public Service Motivation Across Populations: Developing an international instrument and addressing issues of measurement invariance. Journal of Public Administration Research and Theory 23(1), 79-102.

Kropf, Annika (2010). Resource abundance vs. resource dependence in crosscountry growth regressions. OPEC Energy Review 34(2), 107-130.

Krueger, Anne O (1974). The Political Economy of the Rent-Seeking Society. The American Economic Review 64(3), 291-303.

Lentz, Carola (2014). I take an oath to the state, not the government: career trajectories and professional ethics of Ghanaian public servants. States at Work: Dynamics of African bureaucracies. Leiden: Brill.

Leonard, David K (1991). African successes: Four public managers of Kenyan rural development. Berkeley: University of California Press. 
Lewis, Peter (2009). Growing Apart: Oil, politics, and economic change in Indonesia and Nigeria. University of Michigan Press.

Mahdavy, Hossein (1970). The Patterns and Problems of Economic Development in Rentier States: The case of Iran. Studies in Economic History of the Middle East, 428-67.

McCubbins, Mathew, Roger Noll, and Barry Weingast (1987). Administrative Procedures as Instruments of Political Control. The Journal of Law, Economics, and Organization 3(2), 243-277.

Menaldo, Victor (2016). The Institutions Curse. Cambridge University Press.

Moe, Terry M (1989). The Politics of Bureaucratic Structure. In J. E. Chubb and P. E. Peterson (Eds.), Can the Government Govern?, Volume 267, pp. 285-323. Washington: The Brookings Institution.

Morrison, Kevin M (2009). Oil, Nontax Revenue, and the Redistributional Foundations of Regime Stability. International Organization 63(1), 107-138.

Morrison, Kevin M (2014). Nontaxation and Representation. Cambridge University Press.

Odedokun, Matthew O (1990). Flow-of-Funds Model as a Tool for Analyzing Budgetary Behavior of Nigerian State Governments: Evidence from the Civilian Era. World Development 18(5), $743-752$.

Oketch, Martin (2014, September). Uganda to Earn Shs9 Trillion from Oil Annually - Tullow. The Daily Monitor.

Oliveros, Virginia (2016). Making it personal: Clientelism, favors, and the personalization of public administration in Argentina. Comparative Politics 48(3), 373-391.

Oliveros, Virginia and Christian Schuster (2018). Merit, Tenure, and Bureaucratic Behavior: Evidence from a Conjoint Experiment in the Dominican Republic. Comparative Political Studies 51(6), 759-792.

Paler, Laura (2013). Keeping the public purse: An experiment in windfalls, taxes, and the incentives to restrain government. American Political Science Review 107(4), 706-725. 
Perry, James L, Annie Hondeghem, and Lois Recascino Wise (2010). Revisiting the motivational bases of public service: Twenty years of research and an agenda for the future. Public administration review $70(5), 681-690$.

Peters, B Guy (2002). Politics of Bureaucracy. Routledge.

Piattoni, Simona (2001). Clientelism, Interests, and Democratic Representation: the European experience in historical and comparative perspective. Cambridge University Press.

Picard, Louis (1980). Attitudes and Development: The District Administration in Tanzania. African Studies Review 23(3), 49-67.

Poteete, Amy R (2003). Ideas, interests, and institutions: Challenging the property rights paradigm in Botswana. Governance 16(4), 527-557.

Price, Robert M (1975). Society and Bureaucracy in Contemporary Ghana. Berkeley: University of California Press.

Prichard, Wilson, Paola Salardi, and Paul Segal (2018). Taxation, Non-Tax Revenue and Democracy: New Evidence Using New Cross-Country Data. World Development 109, 295-312.

Robinson, James A, Ragnar Torvik, and Thierry Verdier (2006). Political Foundations of the Resource Curse. Journal of Development Economics 79(2), 447-468.

Rose-Ackerman (1999). Corruption and Government: Causes, Consequences, and Reform. Cambridge.

Ross, Michael L (1999). The political economy of the resource curse. World politics 51(2), 297-322.

Ross, Michael L (2001a). Does Oil Hinder Democracy? World politics 53(3), 325-361.

Ross, Michael L (2001b). Timber Booms and Institutional Breakdown in Southeast Asia. Cambridge University Press.

Ross, Michael L (2012). The oil curse: how petroleum wealth shapes the development of nations. Princeton: Princeton University Press. 
Ross, Michael L (2015). What Have We Learned About the Resource Curse? Annual Review of Political Science 18, 239-259.

Rosser, Andrew (2006). The Political Economy of the Resource Curse: A Literature Survey.

Sachs, Jeffrey D and Andrew M Warner (2001). The curse of natural resources. European economic review 45(4-6), 827-838.

Saylor, Ryan (2014). State Building in Boom Times: Commodities and coalitions in Latin America and Africa. Oxford University Press.

Shleifer, Andrei and Robert W Vishny (1993). Corruption. The quarterly journal of economics $108(3), 599-617$.

Sigman, Rachel (2015). Which jobs for which boys? Party financing, patronage and state capacity in African democracies. Syracuse University Doctoral Dissertation.

Uganda Bureau of Statistics (2017). Statistical Abstract. Government Report.

World Bank (2016). World Bank Development Indicators. http://data.worldbank.org/datacatalog/world-development-indicators.

Wright, Joseph, Erica Frantz, and Barbara Geddes (2015). Oil and Autocratic Regime Survival. British Journal of Political Science 45(2), 287-306.

Yates, Douglas Andrew (1996). The Rentier State in Africa: Oil rent dependency and neocolonialism in the Republic of Gabon. Africa World Press. 


\section{Appendices}

\section{A Pre-Analysis Plan}

In our pre-analysis plan (anonymized version pasted at the end of this section) we hypothesized that respondents receiving the oil prime treatment would be more likely to agree with the statement that governments should have the right to increase public spending in districts that help get them elected. We further hypothesized that the positive effects of the treatment would likely be greater for those who support the ruling party.

The tests conducted in Sections 5.1 and 5.3 serve as tests of these initial hypotheses. We find no support for them in either country. In conducting these tests, we found instead that treated respondents in Uganda were more likely to disagree with the statement. We have therefore proceeded to shape the paper around these unanticipated negative effects. This approach led us to propose Hypotheses 2, 4 and 5, which were not pre-specified.

The PAP also proposes additional sub-group analysis that we investigate briefly here. We hypothesized that those with longer tenure and those with higher education levels should be less likely to be affected by new revenue, and that higher-level employees are more likely impacted by revenue sources in ways that make them agree more strongly with the statement about directing government revenue to districts that help get them elected. We also hypothesized that organizations that raise their own revenue, rather than depending solely on transfers from government, will be less susceptible to the oil curse.

To test these hypotheses we divided the sample as follows: those above and below the median total years working in the public service (8 years), at the median education level (bachelors degree), mangers and non-managers, and finally, for Ghana, where institutionlevel budget statistics are available for 2017, we divide between institutions who generate at least as much revenue as they are allocated in the government budget. Unfortunately, we are only able to test this final hypothesis in Ghana as we were unable to obtain reliable institution-level budget data for Uganda.

Overall, we find no support for these hypotheses. We do find in Uganda that there is a significant effect (at the 10\% level) for those who are highly educated: they are significantly less likely to agree with the political use of oil funds under treatment. There is no such effect for the lower-educated in Uganda. This supports the hypothesized relationship. 
Table 9: PAP-Specified Sub-Groups

\begin{tabular}{lccc|ccc}
\hline \hline & \multicolumn{3}{c}{ Ghana } & \multicolumn{3}{c}{ Uganda } \\
\hline & $\begin{array}{c}\text { Control } \\
(\mathbf{N})\end{array}$ & $\begin{array}{c}\text { Treatment } \\
(\mathbf{N})\end{array}$ & t-stat & $\begin{array}{c}\text { Control } \\
(\mathbf{N})\end{array}$ & $\begin{array}{c}\text { Treatment } \\
(\mathbf{N})\end{array}$ & t-stat \\
\hline Tenure & & & & & & \\
Short Tenure & 0.75 & 0.69 & 0.58 & 0.60 & 0.46 & 1.69 \\
& $(301)$ & $(317)$ & & $(315)$ & $(315)$ & \\
Long Tenure & 0.52 & 0.50 & 0.16 & 0.54 & 0.42 & 1.04 \\
& $(204)$ & $(217)$ & & $(183)$ & $(196)$ & \\
\hline Education & & & & & & \\
Less than Bachelors & 0.93 & 0.69 & 1.29 & 0.61 & 0.55 & 0.35 \\
& $(92)$ & $(107)$ & & $(72)$ & $(77)$ & \\
Bachelors + & 0.60 & 0.58 & 0.13 & 0.58 & 0.44 & 1.85 \\
& $(416)$ & $(427)$ & & $(430)$ & $(436)$ & \\
\hline Position & & & & & & \\
Non-Managers & 0.70 & 0.64 & 0.74 & 0.56 & 0.45 & 1.42 \\
& $(452)$ & $(474)$ & & $(413)$ & $(439)$ & \\
Managers & 0.31 & 0.37 & -0.39 & 0.68 & 0.50 & 0.96 \\
& $(59)$ & $(65)$ & & $(84)$ & $(72)$ & \\
\hline Institution Funding & & & & & & \\
Not Reliant on Gov & 0.45 & 0.58 & -0.98 & & & \\
& $(147)$ & $(130)$ & & & & \\
Reliant on Gov & 0.68 & 0.70 & 0.28 & & & \\
& $(357)$ & $(356)$ & & & & \\
\hline \hline
\end{tabular}




\section{A.1 Anonymous PAP}

\section{A.1.1 Research Question}

Does the addition of oil revenue to government budgets affect public servant performance? (Note: the full PAP contains more background information on case selection, sampling, etc., which is included in the paper itself and not reproduced here.)

\section{A.1.2 Motivation}

Political theories of the resource curse tend to focus on two main sets of actors: 1) incumbent political leaders incentivized to engage in rentier behavior; and 2) would-be taxpayers lacking fiscal linkage to the state. The potential effects of resource revenue on public servants is considerably less clear. The results of this experiment will deepen our understanding of the processes through which new discoveries of natural resources may undermine state institutions; and the extent to which civil servants are likely to help or hinder the development of a resource curse.

\section{A.1.3 Research Design}

This experiment primes central government employees with information about oil revenue to examine how this information affects attitudes toward political corruption, responsiveness to taxpayer demands, and public service motivation. The primes are used in Ghana and Uganda, two countries where recent discoveries of oil and gas resources are projected to deliver significant sums of additional revenue to government budgets.

The experiment is conducted using a between-subjects design in which respondents within each country randomly receive a treatment prime, a placebo prime or no prime at all (control). Based on a target survey sample of 1500 per country, we anticipate 500 respondents in each country-group.

The treatment provides projected future revenue statistics from the Ministry of Finance (Ghana) or the IMF (Uganda). By priming on the projection of future revenues, we are able to develop similar messages for the two countries despite different stages of oil production Ghana is already actively producing oil while Ugandas oil production is still in development. This approach is also used by de la Cuesta et al. (2017) in a similar experiment conducted with citizens in Ghana and Uganda.

The treatment and placebo messages in the two countries are presented below. The logic of the placebo is that any observed effects from the treatment could be due to generic increases in government revenue, rather than increases that are specific to oil or other natural resources. The control group, which receives no prime at all, is designed to provide a baseline against which those receiving the treatment and the placebo would be compared.

\section{Ghana}

- Treatment: Did you know that over the next few years, government ministries, departments and agencies will receive at least $\$ 500$ million in additional revenue from oil production compared to the last few years? However the amount of revenue collected directly from citizens is unlikely to change. 
- Placebo: Did you know that over the next few years the revenue of government ministries, departments and agencies will increase by at least an additional $\$ 500$ million?

\section{Uganda}

- Treatment: Did you know that over the next few years, government ministries, departments and agencies will receive at least $\$ 500$ million in additional revenue from oil once production begins? However, the amount of revenue collected through taxes from citizens is unlikely to change.

- Placebo: Did you know that over the next few years the revenue of government ministries, departments and agencies will increase by at least an additional $\$ 500$ million?

\section{A.1.4 Hypotheses}

We test three sets of hypotheses corresponding to three possible manifestations of an "oil curse." First we examine the existence of a rentier effect. Respondents receiving the treatment prime should demonstrate greater levels of acceptance for the diversion of state resources for political gain. Second, we test the hypothesis that oil revenue makes government employees less accountable to tax-payers. Respondents receiving the treatment should demonstrate lower levels of agreement with statements about the need to respond quickly to taxpayer requests. Third, we test the hypothesis that knowledge of additional oil revenue makes public service employees more permissive of (non-political) misuse of state finances.

\section{A.1.5 Outcome Variables}

As explained above, we are interested in three types of effects: rentier effects, taxpayer accountability effects, and private corruption effects. All respondents are asked the following three questions and asked to indicate their level of agreement on a 5-point scale.

1. Governments should have the right to increase public spending for districts that help them get elected.

2. Public servants should have the right to delay responding to taxpayer demands for services if they are overburdened with work.

3. It is condonable for a public servant to divert government revenue to cover the costs of medical care for a critically-ill family member.

Finally, for those receiving the placebo prime, we include an additional question in which the respondent is asked what type(s) of revenue come to mind when the enumerator shared the information about government revenue. This enables us to know if the respondent is associating unspecified sources of additional government revenue with oil revenue, thus suggesting that the placebo message may actually be acting as the treatment. 


\section{A.1.6 Empirical Analysis}

We will test the hypotheses using difference-of-means and Mann-Whitney tests. For all tests, we will include models a) in which we pool respondents from both countries; and b) in which we test for differences across the two countries.

Using the control group as a reference point, we will initially test for statistically significant differences in mean levels of agreement on each of the three outcome questions between the treatment group(s) and the control group(s). Mann-Whitney tests and difference-ofproportions using a dichotomous variable measuring percent who agree or strongly agree with the statement will be used for robustness. Should a statistically significant difference be present, we will then conduct the same set of test between the treatment group and the placebo group. For further robustness we will also test differences between the treatment group and the subset of placebo respondents who did NOT associate oil with the generic revenue increase message they received. Finally, we hypothesize the existence of several possible subgroup effects. The subgroup effects and mechanisms are listed in Table 4. For each subgroup, we will conduct the same set of tests as described in the preceding paragraph.

Table 10: Background Indicators: Ghana and Uganda

\begin{tabular}{ll}
\hline \hline Subgroup & Expected Effect \\
\hline Years in Public Service & Those with longer tenure less likely to be affected by new revenue \\
Political association & Ruling party supporters more susceptible to rentier effects \\
Education level & Employees with higher education levels less susceptible to oil curse \\
Grade/Position & Higher-level employees more likely impacted by revenue sources \\
Organization Type & Organizations that raise their own revenue less susceptible to oil curse \\
\hline
\end{tabular}




\section{B Background Indicators}

Table 11: Background Indicators: Ghana and Uganda

\begin{tabular}{lccc}
\hline \hline Indicator & Year & Ghana & Uganda \\
\hline V-Dem Polyarchy (0-1) & 2016 & .671 & .338 \\
V-Dem Free Expression Index (0-1) & 2016 & .867 & .534 \\
Freedom House Political Rights (1-7) & 2015 & 1 & 6 \\
V-Dem Public Sector Corruption (0-1) & 2016 & .705 & .697 \\
V-Dem Executive Corruption (0-1) & 2016 & .583 & .639 \\
V-Dem Impartial Public Administration (-3.5-4.7) & 2016 & .180 & .172 \\
BTI Basic Administration (1-10) & 2015 & 7 & 7 \\
CPIA Public Sector Management Average (1-5) & 2015 & 3.7 & 3.1 \\
\hline
\end{tabular}

All indicators except Freedom House Political Rights are scored such that higher values indicate better scores (more democracy, more capacity, less corruption, etc. 


\section{Political Bureaucrats?}

In this section we show differences across the two countries in the extent to which we might expect bureaucrats to serve as agents of the ruling party. To do so we examine data estimating whether 1) bureaucrats had support from politicians in obtaining their jobs; and 2) whether bureaucrats have helped divert resources to politicians. For reference, we also show estimated levels of personal nepotism in recruitment. Since these are naturally sensitive topics; we ran list experiments to determine whether or not recruitment practices are politicized, and whether respondents had previously diverted resources to a politician or party.

In the political recruitment experiment, treated respondents received a list with the sensitive item below, while control group respondents received a list without sensitive item. The survey question asked respondents to indicate how many of the items in the list helped them get their first job in the public service. The list presented to respondents was as follows:

- Your job application did not contain any errors

- You had a recommendation letter from an international organization

- You benefited from previous work experience

- Sensitive item: You had support from a politician or someone with political links

A similar experiment was used to ask about personal/family connections that helped them get hired into the public service. The lists for that question are shown below. The survey question asked respondents to indicate how many of the items in the list helped them get their first job in the public service. The list presented to respondents was as follows:

- You met the minimum formal requirements for the position

- You had work experience with an international NGO

- You met the official language requirements

- Sensitive item: You had support from family, friends or other personal connections inside public administration

The list experiment asking about diverting resources to a politician or party was as follows: "There are many more activities that public servants undertake in the course of their jobs and daily lives. In regards to requests and opportunities in your job, how many of the following activities have you undertaken in the past two years?". Again, the respondents were asked to indicate how many but not which ones, they have undertaken. Respondents were randomly assigned to receive a list of either three innocuous (non-sensitive) tasks or the same three tasks plus an additional sensitive task: diverting government resources to a party or person with political links. Like the above questions regarding recruitment, this allows public servants to admit to sensitive behavior without it being detected. The list is as follows:

- You helped your manager with an important assignment for your organisation 
- You helped write a report for an international organisation

- You helped a colleague with the completion of a task

- Sensitive item: You helped divert government resources to a party or person with political links

For all questions, we measure the degree to which people agree with the sensitive item by comparing average response rates across the treatment (list of four items) and control (list of three items) groups. If treatment responses are higher on average, then it must be due to agreement with the sensitive item.

In two-tailed t-tests, depicted in Table 12, we find that bureaucrats in Uganda are considerably more likely to have obtained their jobs with the support of a politician, and to have engaged in diverting resources to a political actor, than those in Ghana. This suggests that Uganda's public service may be more politicized that the ruling party, the NRM, has greater political control over the bureaucracy, particularly since it has been in power for 30 years. In both countries, family and friend connections are important to getting jobs in the public service, though slightly more so in Ghana.

Table 12: List Experiment Results

\begin{tabular}{cccc|ccc}
\hline \hline & Ghana & & & Uganda & & \\
\hline & Control & Treatment & t-stat & Control & Treatment & t-stat \\
\hline Political & 1.19 & 1.25 & -1.49 & 1.23 & 1.41 & -4.25 \\
Recruitment & $(836)$ & $(797)$ & & $(747)$ & $(767)$ & \\
Personal & 1.41 & 1.67 & -7.89 & 1.62 & 1.81 & -5.21 \\
Recruitment & $(814)$ & $(820)$ & & $(758)$ & $(754)$ & \\
Divert & 1.87 & 1.92 & -1.31 & 1.69 & 1.84 & -3.86 \\
Resources & $(838)$ & $(791)$ & & $(741)$ & $(775)$ & \\
\hline \hline
\end{tabular}




\section{Institutions Included in the Survey}

Table 13: Institutions Included in the Uganda Survey

\begin{tabular}{|c|c|}
\hline Institution & $\mathrm{N}$ \\
\hline \multicolumn{2}{|l|}{ Ministries } \\
\hline Agriculture, Animal Industry, and Fisheries & 6 \\
\hline Communication and Information Communication Technology & 1 \\
\hline Disaster Preparedness and Refugees & 1 \\
\hline Education and Sports & 111 \\
\hline Energy and Minerals & 1 \\
\hline Finance, Planning and Economic Development & 164 \\
\hline Foreign Affairs & 2 \\
\hline Gender, Labor, and Social Affairs & 65 \\
\hline Health & 84 \\
\hline Internal Affairs & 100 \\
\hline Justice and Constitutional Affairs & 55 \\
\hline Lands, Housing, and Urban Development & 75 \\
\hline Local Government & 17 \\
\hline Public Service & 60 \\
\hline Trade and Industry & 95 \\
\hline Water and Environment & 1 \\
\hline Works and Transport & 114 \\
\hline \multicolumn{2}{|l|}{ Agencies } \\
\hline Civil Aviation Authority & 74 \\
\hline Uganda Revenue Authority & 83 \\
\hline Inspectorate of Government & 2 \\
\hline National Agricultural Advisory Services & 4 \\
\hline National Council of Sports & 3 \\
\hline Public Procurement & 2 \\
\hline Public Service Commission & 4 \\
\hline The Office of the Auditor General & 60 \\
\hline Uganda Electoral Commission & 44 \\
\hline Uganda National Bureau of Standards & 1 \\
\hline Uganda National Examinations Board & 45 \\
\hline Uganda National Roads Authority & 1 \\
\hline Uganda Registration Services Bureau & 47 \\
\hline \multicolumn{2}{|l|}{ Other } \\
\hline Office of the President & 8 \\
\hline Office of the Vice President & 2 \\
\hline Office of the Prime Minister & 86 \\
\hline Total & 1537 \\
\hline
\end{tabular}


Table 14: Institutions Included in the Ghana Survey

\begin{tabular}{|c|c|}
\hline Institution & $\mathbf{N}$ \\
\hline Bank of Ghana & 7 \\
\hline Controller and Accountant General & 37 \\
\hline CSIR Food Research Institute & 23 \\
\hline Copyright Office & 7 \\
\hline Energy Commission & 44 \\
\hline Environmental Protection Agency & 28 \\
\hline Fair Wages and Salaries Commission & 19 \\
\hline Ghana Educational Trust Fund & 24 \\
\hline Ghana AIDS Control Program & 8 \\
\hline Ghana Audit Service & 42 \\
\hline Ghana Cocoa Board & 20 \\
\hline Ghana Investment Fund for Electronic Communication & 28 \\
\hline Ghana Investment Promotion Center & 30 \\
\hline Medical and Dental Council & 16 \\
\hline National Service Secretariat & 30 \\
\hline Ghana Pharmacy Council & 25 \\
\hline Ghana Revenue Authority & 12 \\
\hline Ghana Standards Authority & 71 \\
\hline Ghana Statistical Service & 32 \\
\hline Information Services Department & 39 \\
\hline Lands Commission & 112 \\
\hline Ministry of Communications & 23 \\
\hline Ministry of Defence & 48 \\
\hline Ministry of Education & 67 \\
\hline Ministry of Employment and Labour Relations & 42 \\
\hline Ministry of Energy & 37 \\
\hline Ministry of Finance and Economic Planning & 70 \\
\hline Ministry of Food and Agriculture & 29 \\
\hline Ministry of Foreign Affairs and Regional Integration & 66 \\
\hline Ministry of Gender, Children and Social Protection & 41 \\
\hline Ministry of Health & 77 \\
\hline Ministry of Information & 14 \\
\hline Ministry of Trade and Industry & 62 \\
\hline Ministry of Works and Housing & 24 \\
\hline Ministry of Youth and Sports & 32 \\
\hline National Identification Authority & 60 \\
\hline National Information Technology Agency & 39 \\
\hline National Board for Small Scale Industries & 5 \\
\hline Petroleum Commission & 5 \\
\hline Nursing and Midwifery Council & 55 \\
\hline Office of the Head of the Civil Service & 29 \\
\hline Registrar General's Department & 32 \\
\hline Department of Feeder Roads & 41 \\
\hline Driver Vehicle Licensing Authprity & 27 \\
\hline Other/Not Specified & 5 \\
\hline Forestry Commission & 31 \\
\hline Ghana Health Service & 26 \\
\hline
\end{tabular}




\section{E Calculations of Population Sizes}

In Ghana, we take the total number of government employees listed as of January 2017: 507,052. Given that a number of organizations seem to have missing numbers, we first increase this estimate by $5 \%$. We then subtract the numbers of employees from MDAs that are primarily made up of "street-level" bureaucrats such as the Ghana Education Service and the Ghana Prisons Service, as well as any regional and district offices listed.

In Uganda, the definition of traditional civil service included in the Uganda Statistical Abstract matches closely with the definition of civil servants we sought to interview. However, we did interview respondents in government agencies, which are not considered part of the traditional civil service. To create an estimate of the size of the population from which we drew our sample, we account for two things: growth of the traditional civil service since 2016 (the most recent estimate) and the number of civil servants in government agencies. If the civil service grew from 2016 to 2017 at the same rate it did from 2015 to 2016 (2.7\%), then the traditional civil service at the time of the survey is likely to be 23,585. However, we included agencies. Unfortunately, to our knowledge, there is no reliable estimate regarding the number of people employed by government agencies. To err on the side of caution, we

assume that agencies employ as much staff as the entire civil service. Therefore we double the population estimate to 47,170 . 


\section{F Balance Tests}

Table 15 pools the two country samples into a single regression. The sample is smaller than expected because in this model, we are only predicting assignment to treatment relative to the control, so our sample is cut from 3,116 total to 2,101, which includes all those across the two countries who received either the treatment or the control $(1,064$ received the placebo; if we run a similar regression for assignment to the placebo, we obtain similar null results). Unfortunately, 709 respondents drop from the analysis due to missingness in the data (primarily in terms of the partisan and ruling party supporter variables). If we estimate the model on each country individually, the null results hold.

Table 15: Logit Regression Predicting Assignment to Treatment

\begin{tabular}{lr}
\hline \hline & Treatment \\
\hline Partisan & 0.261 \\
Ruling Party Supporter & $(0.216)$ \\
& -0.341 \\
Fear the Ruling Party & $(0.239)$ \\
& -0.049 \\
Perceptions of Corruption & $(0.129)$ \\
& -0.064 \\
Manager & $(0.119)$ \\
& -0.102 \\
Salary Category & $(0.177)$ \\
& 0.040 \\
Years in Public Service & $(0.066)$ \\
& 0.001 \\
Bachelors & $(0.012)$ \\
Age & -0.151 \\
Female & $(0.159)$ \\
Uganda & -0.005 \\
Constant & $(0.012)$ \\
& 0.121 \\
\hline \hline Significance levels: $* \%$ & $* *: 5 \%$ \\
& $(0.116)$ \\
& 0.033 \\
& $(0.119)$ \\
& 0.330 \\
& $(0.408)$ \\
\hline
\end{tabular}




\section{G Indicators of Connectedness}

The following questions were used to construct a measure of connectedness, enabling us to divide the sample between those who have benefited from government patronage in their careers and those who have not benefited. Corresponding analysis appears in Section 5.3. Respondents are asked to rate the level of importance of the following on a 1-7 scale.

Having friends, family and other personal acquaintances in the public sector can sometimes help one's career. How important has it been for you to have friends, family members or other personal connections in the public sector for the following achievements?

- To get your first job in the public sector

- To advance to a higher position in the public sector

- To get a salary increase in the public sector

Having connections with a politician or someone with political links can sometimes be important in the public sector. How important have connections to a politician or someone with links to political parties or politicians been to you in the following respects?

- To get your first job in the public sector

- To advance to a higher position in the public sector

- To get a salary increase in the public sector 


\section{H Indicators of Public Service Motivation}

The following sixteen indicators are used to construct an index of public service motivation, used in Section 5.4. The questions ask respondents to rate their level agreement with the following statements on a scale of Strongly Disagree (1) to Strongly Agree (5).

- I admire people who initiate or are involved in activities to aid my community

- It is important to contribute to activities that tackle social problems

- Meaningful public service is very important to me

- It is important for me to contribute to the common good

- I think equal opportunities for citizens are very important

- It is important that citizens can rely on the continuous provision of public services

- It is fundamental that the interests of future generations are taken into account when developing public policies

- To act ethically is essential for public servants

- I feel sympathetic to the plight of the underprivileged

- I empathize with other people who face difficulties

- I get very upset when I see other people being treated unfairly

- Considering the welfare of others is very important

- I am prepared to make sacrifices for the good of society

- I believe in putting civic duty before self

- I am willing to risk personal loss to help society

- I would agree to a good plan to make a better life for the poor, even if it costs me money. 


\section{Robustness Using Non-Parametric Tests}

This section reports results of an alternative set of tests of the four main hypotheses. Specifically, we use a non-parametric technique - the Wilcoxon rank-sum (AKA Mann Whitney) test. The Wilcoxon test is a common non-parametric alternative to a t-test. This test is useful because our data are right-skewed and therefore may violate assumptions of normality associated with conventional t-tests. The rank-sum test combines the two samples (treatment and control groups in our case), ranks every value in the sample irregardless of group, computes the sum of the ranks for each sample, then compares the sum of ranks for each group. Table 9 contains results of ranksum tests corresponding to tests appearing in Section 5. For simplicity, we report only the Uganda results. The z-scores shown indicate that the results are similar for all tests.

Table 16: Rank-Sum Test Results - Uganda

\begin{tabular}{lccccc}
\hline \hline \multirow{2}{*}{ model } & \multicolumn{2}{c}{ Control } & \multicolumn{3}{c}{ Treatment } \\
& rank sum & expected & rank sum & expected & Z \\
\hline General (Treatment) & 263840 & 256530 & 255850 & 263260 & -2.080 \\
General (Placebo restricted) & 268210.5 & 268288 & 280417.5 & 280340 & 0.020 \\
& $(512)$ & & $(535)$ & & \\
General (Placebo full) & 255107 & 248733.5 & 233459 & 255107 & -1.892 \\
& $(503)$ & & $(485)$ & & \\
Ruling Party (NRM) & 12136.5 & 11913 & 9599.5 & 9823 & -0.638 \\
Non-NRM & $(114)$ & & $(94)$ & & \\
& 92607.5 & 90000 & 102392 & 105000 & -1.653 \\
Low Job Security & $(288)$ & & $(336)$ & & \\
High Job Security & 45070.5 & 44091 & 45454.5 & 46343 & -0.988 \\
Connected & $(207)$ & & $(218)$ & & \\
& 90929.5 & 88060 & 85785.5 & 88655 & -1.095 \\
Not Connected & $(296)$ & & $(298)$ & & \\
Connected \& Non-NRM & 33647 & 32670 & 32056 & 33033 & -1.181 \\
Not Connected \& Non-NRM & $(180)$ & & $(182)$ & & \\
Low PSM & 107975 & 105455 & 106210 & 108730 & -1.513 \\
& $(322)$ & & $(332)$ & & \\
& 8570 & 8439 & 10151 & 10282 & -0.438 \\
\hline \hline
\end{tabular}




\section{J Treatment Effects by Demographic Groups}

In Table 17 we show treatment effects broken down by demographic group. The treatment effects are negative (consistent with results in the paper) across all groups in Uganda. Men, those with fewer years of service (10 or fewer), and those who are part of the largest ethnic group (Baganda) appear most sensitive to the treatment. In Ghana, the treatment has no statistically significant effect on any single group. While it is beyond the scope of the paper to understand the determinants of job security, political affiliation and patronage network composition, it is worth noting that those with fewer years of service may feel less secure in their jobs, and members of the Baganda ethnic group in Uganda are not co-ethnic with President Museveni and therefore may be more likely to fall outside of the government patronage network. 


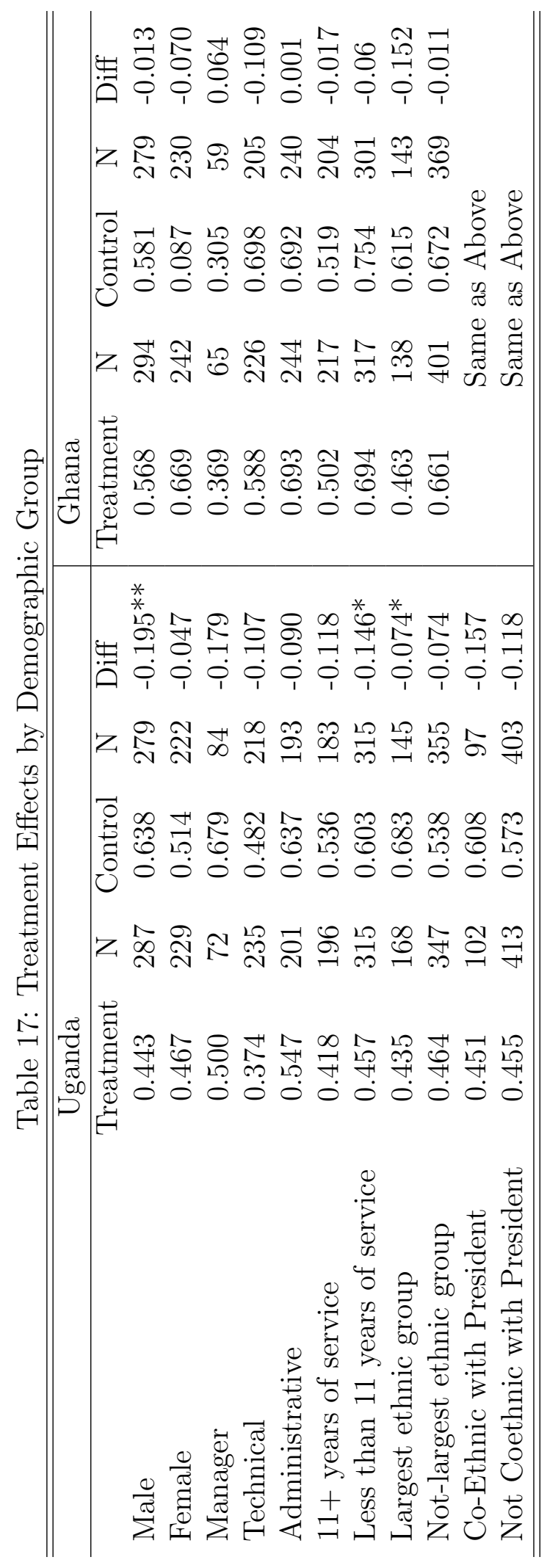




\section{K Ordered Logit Models with Interaction Terms (Hy- potheses $2 \& 4$ )}

In Table 18 we estimate ordered logit models with interaction terms in order to determine if our effects are dependent on the divisions between high and low job security and connectedness. Despite potential limitations of regression analysis for our experimental data (i.e. Freeman 2008, Athey and Imbens 2016), we estimate these models in order to get a sense of their robustness. In each model, we interact our treatment indicator with either our continuous measure of job security or with a continuous measure of connectedness (this variable is simply the average of the variables indicating the importance of personal and political connections but then reversed to be increasing in a lack of connects in order to facilitate an easy comparison with the main results in the manuscript). The results confirm the main results: those who have higher job security and receive the treatment are significantly less likely to agree with the statement regarding permitting the political use of revenues. Likewise, those who are less connected and receive the treatment are significantly less likely to agree with the statement.

Table 18: Order Logit Models Predicting Agreement with Political Spending Statement in Uganda (Hypotheses 2 and 4)

\begin{tabular}{cc}
\hline \hline & Agreement \\
\hline Hypothesis 2 Model & \\
Treatment* Job Security & $-0.208^{* * *}$ \\
& $(0.073)$ \\
$\mathrm{N}$ & 959 \\
\hline Hypothesis 4 Model & \\
Treatment*Unconnected & $-0.225^{* * *}$ \\
& $(0.070)$ \\
$\mathrm{N}$ & 1,000 \\
\hline \hline
\end{tabular}




\section{Attitudes vs. Behavior}

We assess the possible relationship between attitudes observed in the survey and actual behavior by analyzing results from a behavioral game related to pro-sociality that participants played at the end of the Uganda survey compared to results of attitudinal questions.

\section{L.1 Pro-Sociality Analysis}

At the end of the Uganda survey, we asked respondents if they would donate part of their survey compensation to a charity. The precise question on the survey was as follows:

"As mentioned in the beginning of the survey, you will receive a compensation of 10.000 Ush for your participation. You may choose to receive the compensation in full or, if you wish, to anonymously donate some or all of it for a good cause. If you wish to donate, you may choose from one of the following social organisations in Uganda: A. Red Cross Uganda B. Uganda Women's Network (UWONET) C. JOY FOR ELDERLY CARE - UGANDA (JFEC-U). Any donation you make will be doubled by the researchers. In other words, if you donate, the beneficiary organization will receive three times the amount of your donation in Uganda. The international academic researchers who lead this global survey have registered this pledge to double your donation officially. They are bound by university procedures in the United Kingdom and Sweden to honor it. Disclaimer: Please note that the research is independent of and not funded by any of the organizations to which you can make donations. Would you like to donate some or all of your compensation for a good cause to the Red Cross Uganda, Uganda Women's Network or JOY FOR ELDERLY CARE - UGANDA?"

We use responses to this question as another measure to differentiate between those civil servants who are and are not pro-social in their orientation: those who are more willing to donate should also be more pro-social and thus more public service oriented. We thus see this analysis as an additional test of Hypothesis 5. We then run separate difference of means tests between treatment and control groups: one for those who did donate and another for those who did not. The results, which are not statistically significant (using a two-tailed test) for either type, are reported in Table 19. Once again, we find no evidence that public service orientation drives obstruction of the political use of funds.

Table 19: Uganda Donation Game Analysis

\begin{tabular}{lccc}
\hline \hline & $\begin{array}{c}\text { Control } \\
(\mathrm{N})\end{array}$ & $\begin{array}{c}\text { Treatment } \\
(\mathrm{N})\end{array}$ & $\begin{array}{c}\text { Difference } \\
(\text { t-stat) }\end{array}$ \\
\hline Did not Donate & .62 & .49 & .13 \\
& $(335)$ & $(344)$ & $(1.47)$ \\
Donated & .49 & .35 & .14 \\
& $(165)$ & $(168)$ & $(1.27)$ \\
\hline
\end{tabular}




\section{L.2 Correlations of Attitudinal and Behavioral Measures}

While our study does not include behavioral outcomes for the oil revenue experiment, the Uganda survey contained a behavioral measure from a donation game that maps onto attitudinal questions in the survey. We find a high degree of correlation between stated attitudes and behaviors as measured by the donation game. In particular, in Uganda, we find that those who donated to charity are also significantly more likely to agree that 1) "It is important to contribute to activities that tackle social problems", 2) "Considering the welfare of others is very important", 3) "I would agree to a good plan to make a better life for the poor, even if it costs me money", and 4) "I am willing to risk personal loss to help society" than those who did not donate (See Table 20; responses in the survey are degrees of disagreement/agreement on a likert scale with 5 indicating that the respondent strongly agrees with the statement). These correlations show that attitudes of the surveyed bureaucrats do map well onto behaviors, which suggests that our attitudinal outcome measure is likely to correlate with actual behavior; however future research would do well to directly investigate behavior.

Table 20: Attitudinal and Behavioral Measures

\begin{tabular}{lccc}
\hline \hline & $\begin{array}{c}\text { Did Not Donate } \\
(\mathrm{N})\end{array}$ & $\begin{array}{c}\text { Donated } \\
(\mathrm{N})\end{array}$ & $\begin{array}{c}\text { Difference } \\
(\mathrm{t}-\mathrm{stat})\end{array}$ \\
\hline Uganda & & & \\
\hline Contribute to Solve Probs. & 4.69 & 4.81 & -0.12 \\
& $(996)$ & $(507)$ & $(-3.61)$ \\
Consider Welfare of Others & 4.71 & 4.82 & -0.11 \\
& $(994)$ & $(509)$ & $(-3.44)$ \\
Help poor if cost money & 4.15 & 4.40 & -0.26 \\
& $(997)$ & $(508)$ & $(-4.52)$ \\
Risk loss to help society & 3.75 & 3.97 & -0.21 \\
& $(997)$ & $(507)$ & $(-3.16)$ \\
\hline
\end{tabular}




\section{Detecting Social Desirability Bias Using List Ex- periments}

Additional questions in the survey allow us to estimate the risk of social desirability bias in our post-prime question (which asks respondents for the extent to which they agree that governments may direct revenue to politically-supportive districts). We do so by comparing responses from two other questions in the survey: the list experiment on diverting state resources to politicians and a direct question asking how frequently bureaucrats engage in such behavior.

This sensitive item in the list experiment, as presented in Appendix C above, is comparable to the treatment in the revenue prime experiment in that it involves the diversion of state funds for political purposes. The survey also contained a direct question in the survey that asked respondents to report the frequency that "in my institution, public servants help divert government resources to a party or person with political links". This then allows us to compare responses to the list experiment and the direct question. If substantially more people are admitting to diverting funds in the list experiment than in the direct question, we have reason to be concerned that social desirability bias is likely present with regards to responses to the key outcome for the oil revenue prime: agreeing to the use of state funds for political purposes. We find little to no evidence of social desirability bias with regards to admitting to the diversion of public funds to politicians and are confident that the main results reported in the paper are not driven by social desirability bias.

We use the estimation strategy developed by (Blair and Imai, 2012) to estimate the proportions of respondents in the treatment condition of the list experiments who chose the sensitive item. Table 21 reports these proportions for the political use of funds experiment. It is important to note that the percentage of respondents saying yes or no to the sensitive item reported in Table 21 do not add up to exactly 100 because these statistics are only estimates and as such there is error associated with them (the table also reports standard errors for each estimate). The estimates suggest that $8 \%$ in Ghana and $16 \%$ in Uganda responded affirmatively to the sensitive treatment statement that they have "helped divert government resources to the party" in the list experiment. Now, we can compare these estimated proportions to the direct question from the survey. We find that in Ghana 14.6\% report that the diversion of funds to parties happens "all the time or very often" or "often" and the equivalent proportion in Uganda is $12.6 \%$ (the other response options are sometimes, rarely, or never). Therefore, in Uganda we see that fairly similar proportions in the direct questions $(13 \%)$ and the list experiment (16\%) are willing to admit to diverting public funds to the party. We do expect some increase in admitting to sensitive behavior when asked via the list experiment, but the difference between $13 \%$ and $16 \%$ is slight. Given that in Uganda $16 \%$ admit to diverting funds in the experiment and $13 \%$ suggest it is happening in their institution when asked directly, social desirability of responses is not likely an issue in the survey and thus is not likely driving the effects we find in Uganda. In Ghana, surprisingly, more people acknowledge this happens in the direct question than in the survey experiment (probably because the direct question is asking about the overall frequency rather than

specifically whether the person engages in it, or possibly due to the fact that some who admit it directly were not in the treatment condition in the experiment). 
Table 21: Political Use of Funds Experiment: Proportions in Treatment Answering Affirmatively to the Sensitive Item

\begin{tabular}{|c|c|c|c|c|c|c|c|c|}
\hline \multicolumn{5}{|c|}{ Ghana } & \multicolumn{4}{|c|}{ Uganda } \\
\hline Response & No & s.e. & Yes & s.e. & No & s.e. & Yes & s.e. \\
\hline 0 & 4.7 & NA & NA & NA & 3.2 & NA & NA & NA \\
\hline 1 & 22.7 & .02 & 3.0 & .02 & 27.6 & .02 & 11.1 & .02 \\
\hline 2 & 50.1 & .02 & 1.8 & .02 & 42.1 & .02 & 3.4 & .02 \\
\hline 3 & 17.4 & .01 & 1.8 & .00 & 12.5 & .01 & 1.0 & .00 \\
\hline 4 & NA & NA & 1.8 & NA & NA & NA & .7 & NA \\
\hline Total & 94.9 & & 8.4 & & 85.4 & & 16.2 & \\
\hline
\end{tabular}

